\title{
USKLAĐIVANJE HRVATSKOGA ZAKONODAVSTVA S PRAVOM EU-A U PODRUČJU ZAS̆TITE VODA S POSEBNIM OSVRTOM NA SUDJELOVANJE JAVNOSTI I PRISTUP PRAVOSUĐU
}

Izv. prof. dr. sc. Lana Ofa**

\author{
UDK 351.79::061.1EU \\ $351.79(497.59)$ \\ https://doi.org/10.30925/zpfsr.39.1.9 \\ Ur.: 22. siječnja 2018. \\ Pr.: 22. veljače 2018. \\ Izvorni znanstveni rad
}

\section{Sažetak}

Pravna zaštita voda pravno je područje s najviše pokrenutih postupaka protiv država članica Europske unije zbog povreda prava okoliša. Pored toga, u Europskom izvješću o okolišu - Stanje i izgledi 2015., utvrđeno je da su države članice Europske unije daleko od uspostavljanja zdravih vodnih sustava, a cilj ostvarenja dobrog stanja u 2015. postignut je za samo polovinu kopnenih voda. U ovom će se radu analizirati pojedini aspekti pravne zaštite voda koje su države članice Europske unije dužne osigurati temeljem Okvirne direktive o vodama. U radu će se preispitati usklađenost hrvatskoga zakonodavstva s odredbama Okvirne direktive o vodama i Konvencije o pristupu informacijama, sudjelovanju javnosti i pristupu pravosuđu u pitanjima okoliša (Aarhuška konvencija), koje je Sud Europske unije protumačio u presudama C-461/13 Bund für Umwelt und Naturschutz Deutschland ("Weser") te C-664/15 Protect Natur, Arten-und Landschaftschutz Umweltorganisation. U radu će se također ponuditi rješenja za usklađivanje hrvatskoga zakonodavstva s odredbama Okvirne direktive o vodama i Aarhuške konvencije.

Ključne riječi: Okvirna direktiva o vodama, Aarhuška konvencija, Zakon o vodama, Zakon o zaštiti okoliša, praksa Suda Europske unije.

* Dr. sc. Lana Ofak, izvanredna profesorica Pravnog fakulteta u Zagrebu; lana.ofak@pravo.hr. Ovaj rad nastao je u okviru projekta Pravnog fakulteta Sveučilišta u Zagrebu "Novi hrvatski pravni sustav". 


\section{UVOD}

Zaštita voda od onečišćenja jedno je od područja prava okoliša Europske unije (tada: Europskih zajednica) koje se, u skladu s prioritetima utvrđenima u prvom Programu djelovanja Zajednice za okoliš iz 1973. godine, ${ }^{1}$ počelo najranije razvijati. Usvajanje propisa vezanih za zaštitu slatkih voda odvijalo se u tri vala. ${ }^{2} \mathrm{U}$ prvom valu od 1975. do 1980. doneseno je osam direktiva, počevši od Direktive 75/440/EEZ o kvaliteti površinske vode namijenjene zahvaćanju pitke vode ${ }^{3}$ do usvajanja Direktive 80/68/EEZ o zaštiti podzemnih voda od onečišćenja izazvanog određenim opasnim tvarima. ${ }^{4}$ Riječ je bila o direktivama kojima je cilj bio uspostaviti standarde kakvoće vezane za određene tipove vode (površinsku vodu za piće, vodu za kupanje, slatku vodu u kojoj žive ribe, slatku vod u kojoj žive školjkaši, vodu za ljudsku potrošnju $)^{5}$ te zaštititi vodu od onečišćenja opasnim tvarima. ${ }^{6} \mathrm{U}$ drugom valu koji se dogodio 1991. godine, usvojene su Direktiva o pročišćavanju komunalnih otpadnih voda ${ }^{7}$ i Direktiva o zaštiti voda od onečišćenja uzrokovanog nitratima iz poljoprivrednih izvora ${ }^{8}$. U trećem valu donesena je, tzv. Okvirna direktiva o vodama, 2000. godine. ${ }^{9}$

1 Declaration of the Council of the European Communities and of the representatives of the Governments of the Member States meeting in the Council of 22 November 1973 on the programme of action of the European Communities on the environment, SL C 112, 20.12.1973., str. 1.

2 V. Jans, J. H., Vedder, H. H. B., European Environmental Law - After Lisbon, 4th ed., Europa Law Publishing, Groningen, 2012., str. 391. i Grimeaud, D., Reforming EU Water Law: Towards Sustainability?, European Environmental Law Review, vol. 10, br. 2, 2001., str. 41-43. Jans i Vedder govore o četiri vala, budući da pod istim poglavljem (zakonodavstvo koje se odnosi na zaštitu voda) razmatraju zaštitu i slatke i morske vode. Zaštita morske vode neće se razmatrati u ovom radu.

3 Direktiva 75/440/EEZ od 16. lipnja 1975. o kvaliteti površinske vode namijenjene zahvaćanju pitke vode u državama članicama, SL L 194, 25.7.1975., str. 26.

4 Direktiva Vijeća 80/68/EEZ od 17. prosinca 1979. o zaštiti podzemnih voda od onečišćenja izazvanog određenim opasnim tvarima, SL L 20, 26.1.1980., str. 43.

5 Direktiva 75/440/EEZ, op. cit. (bilj. 4), Direktiva Vijeća 79/869/EEZ od 9. listopada 1979. o mjernim metodama i učestalosti uzorkovanja i analize površinske vode namijenjenih zahvaćanju pitke vode u državama članicama, SL L 271, 29.10.1979., str 44., Direktiva Vijeća 76/160/ EEZ od 8. prosinca 1975. o kakvoći vode za kupanje, SL L 31, 5.2.1976., str. 1., Direktiva Vijeća 78/659/EEZ od 18. srpnja 1978. o kvaliteti slatkih voda kojima je potrebna zaštita ili poboljšanje kako bi bile pogodne za život riba, SL L 222, 14.8.1978., str. 1., Direktiva Vijeća 79/923/EEZ od 30. listopada 1979. o propisanoj kvaliteti vode u kojoj žive školjkaši, SL L 281, 10.11.1979., str. 47. i Direktiva Vijeća 80/778/EEZ od 15. srpnja 1980. o kvaliteti vode namijenjene ljudskoj potrošnji, SL L 229, 30.8.1980., str. 11.

6 Direktiva Vijeća 76/464/EEZ od 4. svibnja 1976. o onečišćenju uzrokovanom ispuštanjem određenih opasnih tvari u vodeni okoliš Zajednice, SL L 129, 18.5.1976., str. 23. i Direktiva 80/68/EEZ, op. cit. (bilj. 5).

7 Direktiva Vijeća 91/271/EEZ od 21. svibnja 1991. o pročišćavanju komunalnih otpadnih voda, SL L 135, 30.5.1991., str. 40., Posebno izdanje na hrvatskom jeziku: Poglavlje 15., sv. 001., str. 5 .

8 Direktiva Vijeća 91/676/EEZ od 12. prosinca 1991. o zaštiti voda od onečišćenja uzrokovanog nitratima iz poljoprivrednih izvora, SL L 375, 31.12.1991., str. 1., Posebno izdanje na hrvatskom jeziku: Poglavlje 15., sv. 006., str. 6.

9 Direktiva 2000/60/EZ Europskog parlamenta i Vijeća od 23. listopada 2000. o uspostavi okvira 
Današnje zakonodavstvo EU-a koje se odnosi na područje zaštite slatkih voda može se podijeliti na sljedeće kategorije: (1) opći pravni okvir, (2) posebni načini upotrebe vode te (3) ispuštanje tvari. ${ }^{10} \mathrm{U}$ tablici 1. sažeto su prikazani propisi EU-a koji se odnose na pravnu zaštitu i upravljanje vodama. ${ }^{11}$

Tablica 1. Zakonodavstvo Europske unije u području pravne zaštite i upravljanja vodama

\begin{tabular}{|l|l|}
\hline $\begin{array}{l}\text { Opći pravni } \\
\text { okvir }\end{array}$ & $\begin{array}{l}\text { Direktiva 2000/60/EZ Europskog parlamenta i Vijeća od 23. listopada } 2000 . \\
\text { o uspostavi okvira za djelovanje Zajednice u području vodne politike (dalje u } \\
\text { tekstu: Okvirna direktiva o vodama) } \\
\text { Direktiva Vijeća 91/271/EEZ od 21. svibnja 1991. o pročišćavanju } \\
\text { komunalnih otpadnih voda } \\
\text { Direktiva 2007/60/EZ Europskog parlamenta i Vijeća od 23. listopada } 2007 . \\
\text { o procjeni i upravljanju rizicima od poplava }{ }^{13}\end{array}$ \\
\hline $\begin{array}{l}\text { Posebni načini } \\
\text { upotrebe vode }\end{array}$ & $\begin{array}{l}\text { Direktiva Vijeća 2013/51/Euratom od 22. listopada 2013. o utvrđivanju } \\
\text { zahtjeva za zaštitu zdravlja stanovništva od radioaktivnih tvari u vodi } \\
\text { namijenjenoj za ljudsku potrošnju' }\end{array}$ \\
& $\begin{array}{l}\text { Uredba Komisije (EU) br. 115/2010 od 9. veljače 2010. o utvrđivanju uvjeta } \\
\text { za korištenje aktivnog aluminijevog oksida za uklanjanje fluorida iz prirodnih } \\
\text { mineralnih voda i izvorskih voda }\end{array}$ \\
& $\begin{array}{l}\text { Direktiva 2006/7/EZ Europskog parlamenta i Vijeća od 15. veljače 2006. o } \\
\text { upravljanju kvalitetom vode za kupanje i stavljanju izvan snage Direktive } \\
76 / 160 / E E Z 16\end{array}$ \\
& $\begin{array}{l}\text { Direktiva Vijeća 98/83/EZ od 3. studenoga 1998. o kvaliteti vode } \\
\text { namijenjene za ljudsku potrošnju }\end{array}$ \\
\hline
\end{tabular}

za djelovanje Zajednice u području vodne politike, SL L 327, 22.12.2000., str. 1., Posebno izdanje na hrvatskom jeziku: Poglavlje 15., sv. 001., str. 48.

10 Usp. EUR-Lex, Sažeci zakonodavstva EU-a, Okoliš i klimatske promjene, Zaštita voda i gospodarenje vodama, http://eur-lex.europa.eu/summary/chapter/environment/2006. html?root=2006, pristup: 4. siječnja 2017.

11 Ibid. Iz prikaza su isključeni međunarodni ugovori.

12 SL L 288, 6.11.2007., str. 27., Posebno izdanje na hrvatskom jeziku: Poglavlje 15., sv. 001., str. 186.

13 SL L 296, 7.11.2013., str. 12.

14 SL L 37, 10.2.2010., str. 13., Posebno izdanje na hrvatskom jeziku: Poglavlje 13., sv. 038, str. 241.

15 SL L 64, 4.3.2006., str. 37, Posebno izdanje na hrvatskom jeziku: Poglavlje 15., sv. 006., str. 179 .

16 SL L 330, 5.12.1998., str. 32, Posebno izdanje na hrvatskom jeziku: Poglavlje 15., sv. 006., str. 51. 


\begin{tabular}{|l|l|}
\hline $\begin{array}{l}\text { Ispuštanje } \\
\text { tvari }\end{array}$ & $\begin{array}{l}\text { Direktiva 2008/105/EZ Europskog parlamenta i Vijeća od 16. prosinca } \\
\text { 2008. o standardima kvalitete okoliša u području vodne politike i o izmjeni } \\
\text { i kasnijem stavljanju izvan snage Direktiva Vijeća 82/176/EEZ, 83/513/ }\end{array}$ \\
& EEZ, 84/156/EEZ, 84/491/EEZ, 86/280EEZ i izmjeni Direktive 2000/60/EZ \\
& $\begin{array}{l}\text { Europskog parlamenta i Vijeća' } \\
\text { Direktiva 2010/75/EU Europskog parlamenta i Vijeća od 24. studenoga 2010. } \\
\text { o industrijskim emisijama (integrirano sprečavanje i kontrola onečišcenja) }{ }^{19} \\
\text { Uredba (EZ) br. 648/2004 Europskog parlamenta i Vijeća od 31. ožujka } \\
\text { 2004. o deterdžentima 20 } \\
\text { Direktiva Vijeća 91/676/EEZ od 12. prosinca 1991. o zaštiti voda od } \\
\text { onečišćenja uzrokovanog nitratima iz poljoprivrednih izvora } \\
\text { Direktiva 2006/118/EZ Europskog parlamenta i Vijeća od 12. prosinca 2006. } \\
\text { o zaštiti podzemnih voda od onečišćenja i pogoršanja stanja }{ }^{21}\end{array}$ \\
\hline
\end{tabular}

Pored zakonodavstva prikazanog u tablici 1 ., na zaštitu voda primjenjuju se i drugi propisi prava okoliša Europske unije, od kojih je važno istaknuti Direktivu o procjeni utjecaja određenih javnih i privatnih projekata na okoliš ${ }^{20}$ Direktivu o očuvanju prirodnih staništa i divlje faune i flore ${ }^{21}$ te Direktivu o odgovornosti za okoliš u pogledu sprečavanja i otklanjanja štete u okolišu. ${ }^{22}$ Statistički podatci o postupcima koje pokreće Europska komisija protiv država članica pokazuju da je područje zaštite okoliša na samom vrhu najčešćih povreda. Na kraju 2016. godine bilo je 269 otvorenih postupaka protiv država u tom području. ${ }^{23}$ Samo jedan predmet više (270) imalo je područje unutarnjeg tržišta, industrije, poduzetništva i malih i srednjih poduzeća. ${ }^{24} \mathrm{U}$ području okoliša najviše se postupaka odnosilo na povrede u području zaštite voda i upravljanja vodama $(25,65 \%)$, a iduće najzastupljenije povrede odnose se na gospodarenje otpadom $(21,56 \%) .{ }^{25}$

S obzirom na opsežnost teme zbog velikoga broja propisa Europske unije kojima

17 SL L 348, 24.12.2008., str. 84., Posebno izdanje na hrvatskom jeziku: Poglavlje 15., sv. 006., str. 235.

18 SL L 334, 17.12.2010., str. 17-119., Posebno izdanje na hrvatskom jeziku: poglavlje 15., sv. 15., str. 159.

19 SL L 104, 8.4.2004., str. 1., Posebno izdanje na hrvatskom jeziku: Poglavlje 13., sv. 053., str. 74.

20 Direktiva 2011/92/EU Europskog parlamenta i Vijeća od 13. prosinca 2011. o procjeni učinaka određenih javnih i privatnih projekata na okoliš, SL L 26, 28.1.2012., str. 1., Posebno izdanje na hrvatskom jeziku: Poglavlje 15., sv. 027, str. 3.

21 Direktiva Vijeća 92/43/EEZ od 21. svibnja 1992. o očuvanju prirodnih staništa i divlje faune i flore, SL L 206, 22.7.1992., str. 7., Posebno izdanje na hrvatskom jeziku: Poglavlje 15., sv. 002., str. 14.

22 Direktiva 2004/35/EZ Europskog parlamenta i Vijeća od 21. travnja 2004. o odgovornosti za okoliš u pogledu sprečavanja i otklanjanja štete u okolišu, SL L 143, 30.4.2004., str. 56, Posebno izdanje na hrvatskom jeziku: Poglavlje 15., sv. 026., str. 58.

23 Izvor: Europska komisija, Izvješće Komisije - Praćenje primjene zakonodavstva Europske unije, Godišnje izvješće za 2016., Bruxelles, 6.7.2017., COM/2017/0370 final, str. 26.

24 European Commission, Commission Staff Working Document, Part I: Policy areas, Accompanying the document, Monitoring the application of European Union law, 2016 Annual Report, Brussels, 6.7.2017, SWD(2017) 259 final, str. 27.

25 V. ibid., str. 27. 
se uređuje zaštita voda, ovaj rad će se ograničiti na pojedine aspekte pravne zaštite rijeka koje su države članice dužne osigurati temeljem Okvirne direktive o vodama. U radu će se preispitati usklađenost hrvatskoga zakonodavstva s odredbama Okvirne direktive o vodama i Konvencije o pristupu informacijama, sudjelovanju javnosti i pristupu pravosuđu u pitanjima okoliša koje je Sud Europske unije protumačio u presudama C-461/13 ${ }^{26}$ te C-664/1527.

\section{OKVIRNA DIREKTIVA O VODAMA}

Okvirna direktiva o vodama (dalje i: ODV) teško je razumljiv pravni propis s odredbama koje su u velikoj mjeri složene i stručne. Osim toga, kako u svom mišljenju u predmetu C-461/13 navodi nezavisni odvjetnik Jääskinen, "mnoge poteškoće uzrokuje zakonodavna tehnika koja se sastoji od brojnih upućivanja u jednoj odredbi na drugu odredbu i druge akte kao i na mnoge iznimke kojima nije jasno utvrđen doseg". ${ }^{28}$

Premda je Direktiva usvojena 2000. godine, do sada su u samo pet postupaka nacionalni sudovi podnijeli zahtjev za prethodnu odluku u vezi s tumačenjem njezinih odredaba (prethodno spomenuti predmeti C-461/13 i C-664/15 te C-43/10, ${ }^{29}$

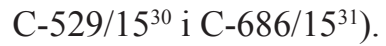

Okvirna direktiva o vodama primjenjuje se na zaštitu kopnenih površinskih voda, prijelaznih voda, obalnih voda i podzemnih voda. Sve te vode na koje se primjenjuje Direktiva pripadaju jednoj od "jedinica" - riječnom slivu, vodnom području i vodnom tijelu. ${ }^{32}$ Riječni sliv je površina tla s koje se sve površinsko otjecanje (putem niza potoka, rijeka, a moguće i jezera) slijeva u more (čl. 2. t. 13. ODV-a). Vodno područje je površina koja se sastoji od jednog ili više susjednih riječnih slivova zajedno $s$ njihovim pripadajućim podzemnim i obalnim vodama i koja čini glavnu jedinicu za upravljanje riječnim slivovima (čl. 2. t. 15. ODV-a). U Republici Hrvatskoj za upravljanje riječnim slivovima utvrđena su dva vodna područja: vodno područje rijeke Dunav i Jadransko vodno područje (čl. 31. st. 1. Zakona o vodama). ${ }^{33}$

Cilj pojma vodnog tijela je utvrditi sve karakteristike i sadašnje stanje voda. ${ }^{34}$

26 C-461/13 - Bund für Umwelt und Naturschutz Deutschland, presuda Suda (veliko vijeće) od 1. srpnja 2015., ECLI:EU:C:2015:433.

27 C-664/15 - Protect Natur-, Arten- und Landschaftschutz Umweltorganisation, Judgment of the Court (Second Chamber) of 20 December 2017, ECLI:EU:C:2017:987 (presuda nije prevedena na hrvatski jezik).

28 Mišljenje nezavisnog odvjetnika Niila Jääskinena od 23. listopada 2014., predmet C-461/13, ECLI:EU:C:2014:2324, točka 4.

29 C-43/10 - Nomarchiaki Aftodioikisi Aitoloakarnanias and Others, Judgment of the Court (Grand Chamber) of 11 September 2012, ECLI:EU:C:2012:560 (presuda nije prevedena na hrvatski jezik).

30 C-529/15 - Folk, Presuda Suda (prvo vijeće) od 1. lipnja 2017., ECLI:EU:C:2017:419.

31 C-686/15 - Vodoopskrba i odvodnja, Presuda Suda (šesto vijeće) od 7. prosinca 2016., ECLI:EU:C:2016:927.

32 Mišljenje nezavisnog odvjetnika, op. cit. (bilj. 30), točka 9.

33 Narodne novine, br. 153/2009, 63/2011, 130/2011, 56/2013, 14/2014.

34 Mišljenje nezavisnog odvjetnika, op. cit. (bilj. 30), točka 10. 
Tijelo površinske vode jasno je određen i značajan dio (element) površinske vode, kao što je jezero, akumulacija, potok, rijeka ili kanal, dio potoka, rijeke ili kanala, prijelazna voda ili pojas obalne vode (čl. 2. t. 10. ODV-a). Tijela površinskih voda unutar vodnog područja svrstavaju se u jednu od sljedećih kategorija - rijeke, jezera, prijelazne vode ili obalne vode - ili kao umjetna ili znatno promijenjena tijela površinskih voda (Prilog II. t. 1.1. i. ODV-a). Umjetno vodno tijelo je tijelo površinske vode stvoreno ljudskom aktivnošću (čl. 2. t. 8.). Znatno promijenjeno vodno tijelo je svako tijelo kojem je zbog fizičkih promjena nastalih ljudskom aktivnošću bitno promijenjen karakter (čl. 2. t. 9. ODV-a).

Sustav upravljanja vodama koji se zahtijeva Direktivom mora ispunjavati nekoliko ključnih pretpostavki.

Kao prvo, ciljevi upravljanja vodama moraju se temeljiti na cjelokupnom ekološkom stanju voda, uzimajući u obzir biološke, fizičko-kemijske i hidromorfološke karakteristike. To zahtijeva od država članica poduzimanje opsežnih analiza kako bi utvrdile koliko je ljudska aktivnost utjecala na ekološko stanje voda te klasificiranje voda prema kategorijama njihovog "stanja". Ekološko stanje svakoga tipa vodnog tijela izražava se u klasifikacijskom sustavu utvrđenim u Prilogu V. Direktive.

Kao drugo, sukladno Direktivi sve vode moraju ostvariti "dobro ekološko stanje", "dobar ekološki potencijal" (znatno promijenjena i umjetna vodna tijela) ili "dobro stanje" (podzemne vode) ili se njihovo vrlo dobro stanje mora održati, uz moguća određene iznimke.

I kao treće, Direktiva zahtijeva da se upravljanje vodama poduzme na sveobuhvatan $\mathrm{i}$ integriran način izradom planova upravljanja riječnim slivovima. Potrebno je izraditi planove za svaki riječni sliv, koji može uključivati više od jedne države članice. Svaki plan definira značajke vodnog područja, prikazuje sve značajne pritiske i utjecaje ljudske aktivnosti na stanje voda, određuje program mjera za ispravljanje problema i utvrđuje program praćenja za opću procjenu stanja voda i za specifične rizike koji im prijete. Pri izradi plana države članice moraju uključiti javnost, a plan se koristi i za izvješćivanje Europske komisije. ${ }^{35}$

\subsection{Predmet C-461/13 Weser-pravna priroda ciljeva zaštite voda}

Predmet C-461/13 Bund für Umwelt und Naturschutz Deutschland e. V. protiv Bundesrepublik Deutschland skraćeno je poznat pod imenom Weser jer se odnosio na tu rijeku koja prolazi kroz grad Bremen i ulijeva se u Sjeverno more kod grada Bremerhavena. Savezno njemačko upravno tijelo, odobrilo je tri projekta koja su se odnosila na uređenje rijeke. U biti riječ je o zahvatima produbljivanja kanala kako bi veliki, osobito kontejnerski brodovi, mogli stići do luka Bremerhaven, Brake i Bremen. Javni interes u korist provedbe ovih projekata očitovao se u održavanju radnih mjesta te jačanju gospodarstva (proizvodnja čelika i automobila). Projektom bi se, također, podupirale njemačke luke u natjecanju protiv konkurencije drugih luka

35 Farmer, A. M. (ur.), Manual of European Environmental Policy, Chapter 5.2: Water Framework Directive, Routledge, London, 2012., str. 3-4., https://ieep.eu/publications/2014/11/chapter-5water-and-marine. 
te bi se ostvarila zaštita prekomorskih dobavnih pravaca za Njemačku, kao i za druge europske zemlje.

Međutim, s druge strane, provedba tih projekata podrazumijevala bi iskopavanje dna rijeke $u$ kanalima, s posljedicama povećanja brzine toka, rasta razine mora tijekom plime, povišenja najniže razine mora, povećanja saliniteta i granica slanih voda te povećanja muljevitosti riječnoga korita i izvan kanala. ${ }^{36}$

Sukladno Okvirnoj direktivi o vodama, ekološko stanje površinskih voda, kako pojašnjava nezavisni odvjetnik Jääskinen u svom mišljenju, utvrđuje se s "pomoću znanstvenog mehanizma koji se temelji na elementima kvalitete, odnosno biološkim (biljne iživotinjske vrste), hidromorfološkim i fizičko-kemijskim, pri čemu se navedeni elementi ocjenjuju ovisno o pokazateljima (na primjer prisutnost beskralježnjaka ili riba u vodotoku)" ${ }^{37}$ Klasifikacija ekološkog stanja površinskih voda sastoji se od pet klasifikacijskih kategorija za biološke elemente (vrlo dobro stanje, dobro stanje, umjereno dobro stanje, siromašno i loše), i po tri kategorije (vrlo dobro stanje, dobro stanje, umjereno dobro stanje) za hidromorfološke i fizikalno-kemijske elemente. ${ }^{38}$ Stanje površinske vode određuje se prema najlošijoj vrijednosti njezina ekološkog i kemijskog stanja. ${ }^{39}$

Ekološko stanje rijeke Weser već se smatra kritičnim i malo je vjerojatno da će rijeka Weser u bliskoj budućnosti doseći dobro ekološko stanje ili dobar ekološki potencijal. ${ }^{40}$ Usprkos negativnim učincima provedbe projekta jaružanja dna rijeke, nadležno upravno tijelo u Njemačkoj odobrilo je projekte. Ocijenilo je da bi se, zbog utjecaja projekata, sadašnje stanje rijeke Weser moglo u nekim dijelovima znatno promijeniti nagore, ali da to ne bi dovelo do promjene razreda stanja prema Prilogu V. Okvirne direktive o vodama. ${ }^{41}$

Protiv te odluke udruga Bund für Umwelt und Naturschutz Deutschland $e V$ podnijela je tužbu pred nadležnim upravnim sudom. Savezni upravni sud (Bundesverwaltungsgericht) odlučio je prekinuti postupak i uputiti Sudu EU-a nekoliko prethodnih pitanja.

Pitanje kojim se Sud EU-a morao pozabaviti jest jesu li ciljevi zaštite voda, koji su propisani u Okvirnoj direktivi o vodama, pravno obvezujući ili ne?

Relevantni dio članka 4. ODV-a, koji ima naslov okolišni ciljevi, glasi: slivovima:

"1. Provodeći programe mjera koji su utvrđeni planovima upravljanja riječnim

(a) za površinske vode

i. Države članice provode potrebne mjere radi sprečavanja pogoršanja stanja svih površinskih voda, uz primjenu stavaka 6. i 7. i ne dovodeći u pitanje stavak 8 .

ii. Države članice štite, poboljšavaju i obnavljaju sva tijela površinske vode,

36 Mišljenje nezavisnog odvjetnika, op. cit. (bilj. 30), točka 22.

37 Ibid., točka 47.

38 V. Alge, T. i dr., Priručnik o načinu određivanja statusa voda i provedbi monitoringa, Zelena akcija, Zagreb, 2012., str. 7-10.

39 Mišljenje nezavisnog odvjetnika, op. cit. (bilj. 30), točka 97. te presuda Suda EU-a C-461/13, op. cit. (bilj. 28) točka 59.

40 Ibid., mišljenje, točka 81.

41 Ibid., točka 24. 
podložno primjeni podtočke iii. za umjetna i znatno promijenjena vodna tijela, u cilju postizanja dobrog stanja površinskih voda najkasnije 15 godina od datuma stupanja na snagu ove Direktive, sukladno odredbama iz Priloga V., podložno primjeni odgoda određenih u suglasnosti sa stavkom 4. i primjeni stavaka 5., 6. i 7., ne dovodeći u pitanje stavak 8.;

iii. Države članice štite i poboljšavaju sva umjetna i znatno promijenjena vodna tijela, u cilju postizanja dobrog ekološkog potencijala i dobrog kemijskog stanja površinskih voda najkasnije 15 godina od datuma stupanja na snagu ove Direktive, u skladu s odredbama iz Priloga V., podložno primjeni odgoda određenih u skladu sa stavkom 4. i uz primjenu stavaka 5., 6. i 7., ne dovodeći u pitanje stavak 8.; ...”.

Pojavila su se dva moguća tumačenja ove odredbe. Prvo je minimalističko tumačenje za koje su se zalagale njemačka i nizozemska vlada. Prema tom tumačenju Okvirna direktiva o vodama samo je sredstvo za planiranje upravljanja vodama te državama članicama ostavlja veliki manevarski prostor u smislu njezine provedbe. Direktiva se ne odnosi na kriterije za odobravanje konkretnih projekata. ${ }^{42} \mathrm{~S}$ druge strane, udruga koja je podnijela tužbu, poljska vlada i vlada Ujedinjenog Kraljevstva kao i Komisija, zalagale su se za drugačije tumačenje prema kojemu se citirane odredbe članka 4. stavka 1. trebaju tumačiti na način da države članice, osim ako nisu predviđene iznimke, moraju uskratiti odobrenje projekta kada on može izazvati pogoršanje stanja tijela površinskih voda ili kada ugrožava postizanje dobrog stanja površinskih voda odnosno dobrog ekološkog potencijala i kemijskog stanja površinskih voda. ${ }^{43}$

Za razliku od Okvirne direktive o vodama koja okolišne ciljeve propisuje u članku 4., u članku 4. stavku 2. Zakona o vodama (dalje i: ZV) propisani su ciljevi upravljanja vodama:

"1. osiguranje dovoljnih količina kvalitetne pitke vode za vodoopskrbu stanovnišstva,

2. osiguranje potrebnih količina vode odgovarajuće kakvoće za različite gospodarske i osobne potrebe, voda $\mathrm{i}$

3. zaštita ljudi i njihove imovine od poplava i drugih oblika štetnog djelovanja

4. postizanje i očuvanje dobrog stanja voda radi zaštite života i zdravlja ljudi, zaštite njihove imovine, zaštite vodnih i o vodi ovisnih ekosustava."

Vidljivo je da su okolišni ciljevi, u određenoj mjeri, sadržani u točki 4. Međutim, detaljnije odredbe o ciljevima zaštite voda propisani su tek u članku 40. Zakona o vodama koji glasi: "Zaštita voda ima za cilj:

- spriječiti daljnje pogoršanje, zaštititi i poboljšati stanje vodnih ekosustava te, s obzirom na potrebe za vodom, kopnenih ekosustava i močvarnih područja izravno ovisnih o vodnim ekosustavima;

- promicati održivo korištenje voda na osnovi dugoročne zaštite raspoloživih vodnih resursa;

- bolje zaštititi i poboljšati stanje vodnog okoliša, među ostalim i putem

42 V. ibid., točka 34.

43 Ibid., točka 33. 
specifičnih mjera za postupno smanjenje ispuštanja, emisija i rasipanja opasnih tvari s prioritetne liste, te prekid ili postupno ukidanje ispuštanja, emisija ili rasipanja opasnih tvari s prioritetne liste;

- osigurati postupno smanjenje onečišćenja podzemnih voda i sprječavati njihovo daljnje onečišćenje, te

- pridonijeti ublažavanju posljedica poplava i suša.

- Ostvarenjem ciljeva iz stavka 1. ovoga članka pridonosi se:

- očuvanju života i zdravlja ljudi,

- osiguravanju dostatnih količina površinskih i podzemnih voda dobre kakvoće potrebnih za održivo, uravnoteženo i pravično korištenje voda,

- znatnom smanjenju onečišćenja podzemnih voda,

- zaštiti kopnenih površinskih voda i morskih voda,

- postizanju ciljeva mjerodavnih međunarodnih ugovora, uključujući i one koji su usmjereni na uklanjanje onečišćenja morskog okoliša sukladno propisima kojima se osigurava prekidanje ili postupno ukidanje ispuštanja, emisije i rasipanja opasnih tvari s prioritetne liste, a s konačnim ciljem postizanja vrijednosti u morskom okolišu bliskih temeljnim koncentracijama tvari koje se prirodno javljaju i koncentracija oko nule za sintetske tvari i

- sprječavanju daljnjeg pogoršanja te zaštiti i poboljšanju stanja vodnih ekosustava te, s obzirom na potrebe za vodom, kopnenih ekosustava i močvarnih područja izravno ovisnih o vodnim ekosustavima.

Zaštita voda ostvaruje se donošenjem provedbenih propisa iz ovoga poglavlja, nadzorom nad stanjem kakvoće voda i izvorima onečišćavanja, kontrolom onečišćenja, zabranom ispuštanja onečišćujućih tvari u vode i zabranom drugih radnji i ponašanja koja mogu izazvati onečišćenje vodnoga okoliša i okoliša u cjelini, građenjem i upravljanjem građevinama odvodnje i pročišćavanja otpadnih voda te drugim mjerama usmjerenim očuvanju i poboljšavanju kakvoće i namjenske korisnosti voda.

Provedba mjera zaštite voda od onečišćenja ne može izravno ili neizravno povećati onečišćenje kopnenih voda.

Zaštita voda uključuje uvijek i zaštitu vodnog okoliša, a gdje je primjenjivo i drugih sastavnica okoliša."

Ako usporedimo odredbe članka 4. ODV-a i članka 40. ZV-a, možemo uočiti da je ZV-om propisan općeniti cilj da "zaštita voda ima za cilj: - spriječiti daljnje pogoršanje ... vodnih ekosustava" (st. 1., prva alineja), ali nigdje nije izrijekom navedena dužnost sprječavanja pogoršanja. Za razliku od toga, u članku 4. stavak 1. točka (a) podtočka i. ODV-a propisana je dužnost država članica da provode (engl. shall implement) potrebne mjere radi sprječavanja pogoršanja stanja svih površinskih voda.

Pored toga, u članku 40. stavku 1 . ZV-a nije naveden cilj postizanja dobrog stanja voda, već je kao cilj propisano "poboljšati stanje vodnih ekosustava" (prva alineja) odnosno "bolje zaštititi i poboljšati stanje vodnog okoliša" (treća alineja). Međutim, postizanje i očuvanje dobrog stanja voda jest naveden kao cilj u točki 4 . članka 4. stavka 2. ZV-a.

Kada, zatim, pogledamo kako je propisano da se zaštita voda u Hrvatskoj 
ostvaruje, vidimo da je u članku 40. stavku 3. ZV-a nabrojano, inter alia, donošenje provedbenih propisa, nadzor nad stanjem kakvoće voda i izvorima onečišćenja, kontrola onečišćenja, zabrana ispuštanja onečišćujućih tvari u vode i drugih radnji i ponašanja koja mogu izazvati onečišćenje vodnog okoliša. Nažalost, ne postoji jasna odredba koja propisuje zabranu pogoršanja stanja voda.

Može se činiti da se ovim odredbama "samo" propisuju ciljevi kojima se teži i koji se nastoje postići te da stoga nije toliko važan način na koji su odredbe članka 4. ODV-a prenesene u Zakon o vodama. Međutim, u predmetu Weser njemački Savezni upravni sud je upravo to želio saznati, jesu li ciljevi propisani u Okvirnoj direktivi o vodama samo "težnje” ili su ipak pravnoobvezujući?

Prema shvaćanju Suda EU-a Direktiva u članku 4. stavku 1. propisuje dva različita cilja, koji su međusobno povezani. Prvi je cilj obveza sprečavanja pogoršanja, a drugi je cilj obveza poboljšanja. ${ }^{44}$ Sud je sagledao kakvo značenje ove obveze imaju kod odlučivanja o odobravanju zahvata čija bi provedba mogla osujetiti njihovo ispunjenje. Znači li da se zahvat ne može odobriti ako bi mogao izazvati pogoršanje stanja tijela površinskih voda ili kad ugrožava postizanje dobrog stanja površinskih voda (osim ako nije predviđena iznimka) ${ }^{45}$

Sud EU-a presudio je u korist takvog tumačenja. Odbio je tumačiti Direktivu na način da je riječ o pukom političkom instrumentu, odnosno da se obveze iz članka 4. stavka 1. (a) (i) do (iii) odnose samo na najbolja nastojanja država članica. ${ }^{46}$

Sud EU-a odgovorio je da članak 4. st. 1. točku (a) podtočke (i) do (iii) Okvirne direktive o vodama o okolišnim ciljevima "treba tumačiti na način da države članice, osim ako nije predviđeno izuzeće, moraju uskratiti odobrenje projekta kada on može izazvati pogoršanje stanja tijela površinskih voda ili kada ugrožava postizanje dobrog stanja površinskih voda odnosno dobrog ekološkog potencijala i kemijskog stanja tih voda do datuma određenog tom direktivom". ${ }^{47}$

Koje su konkretne posljedice ove presude? Ciljevi zaštite okoliša propisani u članku 4. stavku 1. točki (a) ODV-a su pravno obvezujući. Što to znači? Čak i ako neki zahvat ispunjava sve uvjete temeljem drugih mjerodavnih propisa, ako će se zbog njegove provedbe pogoršati stanje površinskih voda, tada se ne smije izdati odobrenje za provedbu projekta. Međutim, moguće su iznimke. One su propisane u članku 4. stavku 7. ODV-a i prenesene su u članak 54.a Zakona o vodama. Iznimke su usporedno prikazane u tablici 2.

44 Presuda Suda EU-a C-461/13, op. cit. (bilj. 28), točka 39.

45 Ibid., točka 29.

46 Paloniity, T., The Weser Case: Case C-461/13 Bund v Germany, Journal of Environmental Law, 2016., 28, str. 154.

47 Presuda Suda EU-a C-461/13, op. cit. (bilj. 28), točka 51. 
Tablica 2. Iznimke od obveze sprječavanja pogoršanja i obveze poboljšanja

\begin{tabular}{|c|c|}
\hline Okvirna direktiva o vodama & Zakon o vodama \\
\hline $\begin{array}{l}\text { Članak } 4 \text {. } \\
\text {.. } \\
\text { 7. Države članice ne krše ovu Direktivu } \\
\text { u slučaju: } \\
\text { - da je nepostizanje dobrog stanja } \\
\text { podzemnih voda, dobrog ekološkog } \\
\text { stanja ili, gdje je to odgovarajuće, dobrog } \\
\text { ekološkog potencijala, ili nesprečavanje } \\
\text { pogoršanja stanja površinskih ili } \\
\text { podzemnih voda posljedica novonastalih } \\
\text { promjena fizičkih karakteristika tijela } \\
\text { površinske vode ili promjena razine tijela } \\
\text { podzemne vode, ili } \\
\text { - da je nesprečavanje pogoršanja od } \\
\text { vrlo dobrog stanja prema dobrom stanju } \\
\text { tijela površinske vode rezultat novih } \\
\text { ljudskih aktivnosti u području održivog } \\
\text { razvoja } \\
\text { ako su zadovoljeni svi sljedeći uvjeti: } \\
\text { (a) poduzeti su svi praktični koraci za } \\
\text { ublažavanje negativnog utjecaja na stanje } \\
\text { vodnog tijela; } \\
\text { (b) razlozi tih modifikacija i promjena } \\
\text { izričito su navedeni i objašnjeni u planu } \\
\text { upravljanja riječnim slivom iz članka } 13 \text {. } \\
\text { te da se ciljevi preispituju svakih šest } \\
\text { godina; } \\
\text { (c) razlozi tih modifikacija i promjena } \\
\text { od prevladavajućeg su javnog interesa } \\
\text { i/ili su koristi za okoliš i društvo od } \\
\text { postizanja ciljeva iz stavka } 1 \text {. manji od } \\
\text { koristi za ljudsko zdravlje, sigurnost } \\
\text { i održivi razvoj, koje proizlaze iz tih } \\
\text { modifikacija i promjena; i } \\
\text { (d) korisni ciljevi kojima služe te } \\
\text { promjene stanja vode ne mogu se iz } \\
\text { tehničkih razloga ili zbog nerazmjernih } \\
\text { troškova postići drugim sredstvima koja } \\
\text { predstavljaju znatno bolju ekološku } \\
\text { opciju. }\end{array}$ & $\begin{array}{l}\text { Neodstupanja od postizanja ciljeva zaštite voda } \\
\text { Članak 54.a } \\
\text { Ne smatra se odstupanjem od postizanja ciljeva } \\
\text { zaštite voda ako se ne uspije postići dobro stanje } \\
\text { podzemnih voda, dobro ekološko stanje ili, gdje } \\
\text { je to odgovarajuće, dobar ekološki potencijal, } \\
\text { ili spriječiti pogoršanje stanja površinskih ili } \\
\text { podzemnih voda uslijed novonastalih promjena } \\
\text { fizičkih karakteristika površinskih voda ili promjena } \\
\text { razine podzemnih voda, kada su ispunjeni svi } \\
\text { sljedeći uvjeti: } \\
\text { - da su poduzeti svi praktični koraci za ublažavanje } \\
\text { negativnog utjecaja na stanje vode; } \\
\text { - da su razlozi tih izmjena ili promjena izričito } \\
\text { navedeni i objašnjeni u Planu upravljanja vodnim } \\
\text { područjima, te da se ciljevi revidiraju svakih } 6 \\
\text { godina; } \\
\text { da su razlozi tih izmjena i promjena od } \\
\text { prevladavajućeg javnog interesa i/ili da su } \\
\text { koristi za okoliš i društvo od postizanja ciljeva } \\
\text { zaštite voda manji od koristi za ljudsko zdravlje, } \\
\text { sigurnost i održivi razvoj koje proizlaze iz tih } \\
\text { izmjena i promjena te } \\
\text { - da se korisni ciljevi kojima služe te promjene } \\
\text { stanja vode ne mogu iz tehničkih razloga ili zbog } \\
\text { nerazmjernih troškova postići drugim sredstvima } \\
\text { koja predstavljaju znatno bolju ekološku } \\
\text { varijantu. } \\
\text { Ne smatra se odstupanjem od postizanja ciljeva } \\
\text { zaštite voda i ako se ne uspije spriječiti pogoršanje } \\
\text { od vrlo dobrog stanja prema dobrom stanju } \\
\text { površinskih voda uslijed novih ljudskih djelatnosti } \\
\text { u sklopu održivog razvoja kada su ispunjeni svi } \\
\text { uvjeti iz stavka } 1 \text {. ovoga članka. }\end{array}$ \\
\hline
\end{tabular}

U Europskom izvješću o okolišu - Stanje i izgledi 2015., utvrđeno je da su države članice daleko od ispunjenja ciljeva vodne politike i uspostavljanja zdravih vodnih sustava. Cilj ostvarenja dobrog statusa u 2015. postignut je za samo polovinu 
kopnenih voda ${ }^{48} \mathrm{U}$ tom pogledu znanstvenici dobro predviđaju da će pravni režim koji se primjenjuje na vode prijeći u "stanje iznimaka" ${ }^{49}$ To znači da će se češće početi koristiti iznimke propisane u članku 4. stavku 7. Okvirne direktive o vodama. ${ }^{50}$ Sukladno članku 4. stavku 7. Direktivi, razlozi promjena moraju biti izričito navedeni i objašnjeni u Planu upravljanja vodnim područjima te se ciljevi moraju revidirati svakih šest godina. Praktična posljedica toga mogla bi značiti da će se pojedini projekti morati "staviti na čekanje" do narednog krug revidiranja, budući da se planovi upravljanja vodnim područjima mijenjaju svakih šest godina. Za očekivati je da će u pojedinim državama članicama doći do osmišljavanja novih postupaka odobravanja projekata koji će morati biti usklađeni s Okvirnom direktivom o vodama i presudom Suda EU-a u predmetu Weser.

Drugo pitanje na koje je Sud EU-a morao dati odgovor jest što to znači "pogoršanje stanja" tijela površinskih voda? Dva su moguća tumačenja tog pojma. Njemačka, nizozemska i poljska vlada te vlada Ujedinjenog Kraljevstva zalagale su se za, tzv. teoriju o razredu prema kojoj pogoršanje stanja obuhvaća samo negativne promjene koje dovode do klasificiranja rijeke u niži razred u smislu Priloga V. ODV-u. ${ }^{51}$ Njemačko upravno tijelo odobrilo je projekt upravo jer su ocijenili da pogoršanje neće biti toliko da će dovesti do toga da rijeka padne u niži razred.

Udruga koja je podnijela tužbu, zalagala se za, tzv. status quo teoriju, prema kojoj pogoršanje stanja obuhvaća sve promjene stanja vodnog tijela. ${ }^{52}$ Komisija je pak smatrala da pogoršanje postoji ako se stanje barem jednog elementa kvalitete kojim se procjenjuje ekološko stanje površinskih voda u smislu Priloga V. ODV-u pogorša za jedan razred. ${ }^{53}$ Sud EU-a prihvatio je tu, tzv. "teoriju o kvaliteti elementa" prema kojoj "dolazi do pogoršanja čim se stanje barem jednog od elemenata kvalitete u smislu Priloga V. toj direktivi pogorša za jedan razred, iako takvo pogoršanje elementa kvalitete ne znači pogoršanje klasifikacije kvalitete tijela površinskih voda u cijelosti. Međutim, ako se dotični element kvalitete već nalazi u najnižem razredu, svako pogoršanje koje se na njega odnosi predstavlja "pogoršanje stanja" tijela površinskih voda u smislu navedenog članka 4. stavka 1. točke (a) podtočke (i)." ${ }^{.54}$

Ovdje se otvara jedno važno pitanje. Što ako se radi o zahvatu (projektu) za koji se ne mora provesti procjena utjecaja na okoliš, a nema ni mogućeg značajnijeg utjecaja na ekološku mrežu? Kako zainteresirana javnost može sudjelovati u postupcima izdavanja odobrenja za takve projekte (vodopravni akti) koji mogu dovesti do pogoršanja ekološkog stanja površinskih voda? Naime, kada pogledamo Okvirnu direktivu o vodama države članice, ona u članku 14. stavku 1. propisuje da su države

48 Europska agencija za okoliš, Europsko izvješće o okolišu - stanje i izgledi 2015.: sinteza, 2015., str. 62.

49 Salm, D., The Case for Smart Governance in European Water Law, u: Vanheudsen B., Squintani, L. (eds.), EU Environmental and Planning Law Aspects of Large-Scale Projects, Cambridge, Intersentia, 2016., str. 223.

50 Ibid.

51 Mišljenje nezavisnog odvjetnika, op. cit. (bilj. 30), točka 89.

52 Ibid., točka 90.

53 Ibid., točka 88.

54 Presuda Suda EU-a C-461/13, op. cit. (bilj. 28), točka 70. 
članice dužne poticati aktivno uključivanje svih zainteresiranih strana u njezinu provedbu, a osobito u izradu, preispitivanje i nadopunjavanje planova upravljanja riječnim slivovima. Hrvatski zakonodavac potpuno je zanemario dužnost iz prvoga dijela citirane odredbe te je jedino propisao da javnost ima pravo sudjelovati u izradi planskih dokumenata za upravljanje vodama (čl. 5. st. 8. ZV-a). Stoga, zaključno, smatramo da sudjelovanje javnosti u pitanjima koji se odnose na zaštitu voda nije usklađeno s pravom EU-a, o čemu će više riječi biti u idućem poglavlju.

\section{AARHUŠKA KONVENCIJA}

Konvencija o pristupu informacijama o okolišu, sudjelovanju javnosti i pristupu pravosuđu u pitanjima okoliša zaključena 1998. u Aarhusu (Danskoj), stupila je na snagu 2001. godine. Skraćeno se naziva Aarhuškom konvencijom (u daljnjem tekstu i: Konvencija). Cilj joj je doprinijeti zaštiti prava svake osobe sadašnjega i budućih naraštaja na život u okolišu pogodnom za njegovo ili njezino zdravlje i dobrobit. Radi ostvarenja navedenog cilja svaka stranka Konvencije dužna je jamčiti pravo pristupa informacijama, sudjelovanja javnosti u odlučivanju o okolišu i pristupa pravosuđu u pitanjima okoliša sukladno njezinim odredbama. Europska unija (tada: Europska zajednica $)^{55}$ potpisala je Konvenciju 25. lipnja 1998. u Aarhusu, međutim ratificirala ju je gotovo sedam godina kasnije kada je Vijeće Europske unije usvojilo Odluku o sklapanju Aarhuške konvencije u ime Europske zajednice. ${ }^{56}$ Aarhuška konvencija je u Hrvatskoj stupila na snagu 25. lipnja 2007. godine. ${ }^{57}$

Odredbe Konvencije samo su minimum standarda ispod kojih stranka Konvencije ne smije ići. Stranke imaju pravo zadržati ili uvesti mjere kojima se osigurava širi pristup informacijama, opsežnije sudjelovanje javnosti u odlučivanju i širi pristup pravosuđu u pitanjima okoliša nego što se to traži Konvencijom. ${ }^{58}$

Sudjelovanje javnosti u odlučivanju u pitanjima okoliša pojavljuje se kao jedno od važnijih sredstava zaštite okoliša. Temelji se na tomu da je okoliš opće dobro, pa se odluke tijela javne vlasti koje bi mogle utjecati na okoliš moraju donijeti transparentno i uz uključivanje svih zainteresiranih. Tri se članka Aarhuške konvencije bave sudjelovanjem javnosti u odlučivanju o pitanjima okoliša - članak 6. koji se tiče odlučivanja o određenim djelatnostima, članak 7. o sudjelovanju u vezi s planovima, programima i politikama te članak 8. o sudjelovanju tijekom izrade

55 Ugovor iz Lisabona o izmjenama i dopunama Ugovora o Europskoj uniji i Ugovora o uspostavi Europske zajednice koji je stupio na snagu 1. prosinca 2009. ukinuo je razlikovanje između Europske zajednice i Europske unije te isključivo zadržava naziv Europska unija. Međutim, u vrijeme potpisivanja Aarhuške konvencije, Europska unija nije imala pravnu osobnost, već je međunarodnu pravnu osobnost imala samo Europska zajednica.

56 Council Decision of 17 February 2005 on the conclusion, on behalf of the European Community, of the Convention on access to information, public participation in decision-making and access to justice in environmental matters (2005/370/EC), SL L 124, 17.05.2005., str. 1.

57 Zakon o potvrđivanju Konvencije objavljen je 12. siječnja 2007. u Narodnim novinama (dalje: NN) - Međunarodni ugovori, br. 1/2007, a Konvencija je u Hrvatskoj stupila na snagu devedesetoga dana od datuma kada je položila ispravu o ratifikaciji sukladno čl. 20. st. 3. Konvencije.

58 Čl. 3. st. 5. Aarhuške konvencije. 
propisa i općenormativnih akata.

Konvencija razlikuje pojmove javnosti i zainteresirane javnosti kojoj priznaje određena veća prava u odnosu na ostale pripadnike javnosti. Zainteresirana javnost definira se kao javnost na koju utječe ili bi moglo utjecati odlučivanje o okolišu ili koja je za to zainteresirana. Nevladine organizacije koje rade na promicanju zaštite okoliša i udovoljavaju svim zahtjevima domaćeg zakonodavstva smatraju se zainteresiranima (čl. 2. t. 5. Konvencije).

U članku 6. Konvencije propisuje se obveza stranaka da omoguće javnosti sudjelovanje u donošenju odluke o tomu treba li dopustiti određene djelatnosti. To se, ponajprije, odnosi na djelatnosti koje su navedene u Dodatku I. Konvencije (st. 1. podstavak (a)). Radi se o djelatnostima iz područja energetike, proizvodnje i prerade metala, prerade minerala, kemijske industrije, gospodarenja otpadom i drugim djelatnostima. Za njih se samom normom pretpostavlja da imaju značajne učinke na okoliš. Međutim, članak 6. primjenjuje se i na odluke o djelatnostima izvan opsega Dodatka I., a koje mogu imati značajne učinke na okoliš (st. 1. podstavak (b)). Pored toga, primjena članka 6. proširena je, na odgovarajući način i gdje je to prikladno, i na razmatranja i dopunjavanja radnih uvjeta prethodno spomenutih djelatnosti (st. 10.).

Stranke Konvencije dužne su pripadnicima zainteresirane javnosti osigurati pristup sudskoj kontroli donošenja odluka kojima se odobravaju djelatnosti koje mogu imati značajne učinke na okoliš (čl. 9. st. 2. Konvencije). No, pristup pravosuđu mora biti osiguran i u svim drugim slučajevima kada se određenim odlukama, radnjama ili propustima krše propisi koji se odnose na okoliš. To znači da javnost mora imati osiguran pristup sudskoj kontroli odluka, radnji i propusta tijela javne vlasti i privatnih osoba koji su u suprotnosti s odredbama domaćeg zakonodavstva iz područja zaštite okoliša (čl. 9. st. 3. Konvencije).

Domaće zakonodavstvo koje se odnosi na okoliš ne obuhvaća samo propise koji izričito u svom naslovu sadrže riječ "okoliš” (primjerice Zakon o zaštiti okoliša), već sve propise koji se na neki način odnose na okoliš. Stoga radnje ili propusti koji su protivni propisima o prostornom planiranju, gospodarenju otpada ili iskorištavanju prirodnih resursa, također mogu biti pokriveni člankom 9. stavkom 3. neovisno o tomu što se radi o posebnim propisima (Zakonu o prostornom planiranju, Zakonu o održivom gospodarenju otpada ili Zakonu o zaštiti prirode).

Za države koje su članice Europske unije, pojam "nacionalno" ili "domaće" pravo ili zakonodavstvo uključuje i pravo Europske unije koje obvezuje državu članicu. To znači da se radnje ili propusti, koji su protivni direktivama ili drugim propisima Unije i koji su primjenjivi pred nacionalnim sudovima i tijelima javne vlasti, mogu osporavati temeljem članka 9. stavka 3. 


\subsection{Predmet C-664/15 Protect-sudjelovanje javnosti i pristup pravosu- đи и području zaštite voda}

U predmetu C-664/15 Protect Natur-, Arten- und Landschaftsschutz Umweltorganisation protiv Bezirkshauptmannschaft Gmünd (predmet će se skraćeno zvati Protect) austrijski Visoki upravni sud postavio je Sudu EU-a određena pitanja koja su se odnosila na postupak izdavanja odobrenje za vađenje vode iz rijeke radi proizvodnje snijega za skijalište.

Zahtjev nositelja zahvata (društvo Aichelberglift) prvotno se razmatrao u postupku ocjene prihvatljivosti zahvata za ekološku mrežu Natura 2000 koji se temelji na članku 6. stavku 3. Direktive o staništima. Nadležno nacionalno tijelo odlučilo je da zbog malog utjecaja koji projekt ima na okoliš nije bilo razloga za odbijanje zahtjeva..$^{59}$ Nakon toga, zahtjev nositelja zahvata razmatrao se u zasebnom upravnom postupku na temelju austrijskog Zakona o vodama (Wasserrechtsgesetz, u daljnjem tekstu: WRG). Protect Natur-, Arten- und Landschaftsschutz Umweltorganisation (u daljnjem tekstu: Protect), organizacija za zaštitu okoliša, podnijela je zahtjev da sudjeluje kao stranka u tom postupku na temelju članka 6. stavka 3. Direktive o staništima i članka 9. stavka 3. Aarhuške konvencije.

Sukladno austrijskom Zakonu o općem upravnom postupku (§ 8.) (Allgemeines Verwaltungsverfahrensgesetz, u daljnjem tekstu: $A V G$ ), sudionici u upravnom postupku su osobe koje koriste usluge koje obavljaju javnopravna tijela ili na koje utječu djelatnosti takvih tijela, a ako su u uključene u predmet na temelju pravnog ovlaštenja ili pravnog interesa, takve su osobe stranke u postupku. ${ }^{60}$ Prema austrijskom Zakonu o vodama $W R G$-u (§ 102.), stranke u postupku su, inter alia, podnositelj zahtjeva te osobe koje imaju obvezu činjenja, trpljenja ili suzdržavanja, ili osobe na čija se prava na neki drugi način utječe, osobe s ribolovnim pravima ili pravima korištenja, kao i osobe koje izjavljuju sukob. Nadalje, zainteresirane osobe u smislu stavka 8. $A V G$-a su, osobito, one osobe koje, u skladu s predmetom rasprave o kojoj je riječ i u onoj mjeri u kojoj im već nije bio odobren položaj, imaju interes za javnu upotrebu, osobe koje imaju stvarna prava u pogledu zahvaćene nekretnine, sve osobe koje bi imale koristi od očuvanja ili napuštanja postrojenja ili ukidanja prava na vodu te, u svrhu postupka za prigovor na projekte, sve osobe koje se trebaju smatrati strankama kada se realiziraju ti projekti. Zainteresirane osobe imaju pravo objasniti svoje interese tijekom postupka, ali nemaju pravo podnijeti prigovore. ${ }^{61}$

Nadležno okružno tijelo tijekom postupka izdavanja odobrenja za vađenje vode održalo je raspravu u kojoj je Protect istaknuo prigovore koji su odbijeni jer ta udruga nije navela povredu nikakvih prava na temelju $W R G$-a, te stoga nije mogla biti stranka u postupku u skladu s nacionalnim pravilima. Nadležno okružno tijelo usvojilo je zahtjev nositelja zahvata za izdavanje odobrenja. ${ }^{62}$ Protect je tu odluku neuspješno

59 Mišljenje nezavisne odvjetnice Eleanor Sharpston od 12. listopada 2017., predmet C-664/15, ECLI:EU:C:2017:760, točka 22.

60 Presuda Suda EU-a C-664/15, op. cit. (bilj. 29), točka 14.

61 Ibid., točka 15.

62 Mišljenje nezavisne odvjetnice, op. cit. (bilj. 61), točka 24. 
pobijao pred Zemaljskim upravnim sudom u Donjoj Austriji koji je utvrdio da Protect nije imao položaj stranke u upravnom postupku jer se tijekom tog postupka nije pozvao na povredu prava koja se štite temeljem propisa koji uređuju pitanja vezana za vode.

Protect je zatim, protiv presude tog suda pokrenuo postupak pred Visokim upravnim sudom. Visoki upravni sud je zastao s postupkom i postavio tri pitanja Sudu EU-a o pravu organizacija za zaštitu okoliša da sudjeluju u postupcima i osporavaju odluke koje se donose temeljem Okvirne direktive o vodama.

Prvo je pitanje glasilo: priznaje li članak 4. Okvirne direktive o vodama ili ta direktiva kao cjelina, organizaciji za zaštitu okoliša - u postupku u kojem nije potrebno provesti procjenu utjecaja na okoliš u skladu s Direktivom 2011/92/EU prava za zaštitu kojih ona ima pristup upravnim ili sudskim postupcima u skladu s člankom 9. stavkom 3. Aarhuška konvencije?

U prvom dijelu odgovora, Sud EU-a ponovio je svoje zaključke iz presude Weser da članak 4. stavak 1. točka (a) Direktive 2000/60 ne propisuje samo ciljeve planiranja upravljanja, nego nameće obvezu sprječavanja pogoršanja stanja vodnih tijela koja ima obvezujuće učinke na države članice u svakoj fazi postupka propisanih tom Direktivom, a osobito tijekom postupka odobravanja dozvola za pojedine projekte. ${ }^{63}$

Sud EU-a zatim je utvrdio da učinkovitost Okvirne direktive o vodama i njezin cilj zaštite okoliša zahtijevaju da se pojedinci ili, ako je prikladno, pravilno osnovana organizacija za zaštitu okoliša mogu osloniti na tu Direktivu u sudskom postupku. ${ }^{64}$ Jednako tako, nacionalni sudovi moraju biti u mogućnosti uzeti u obzir Direktivu kao dio prava EU-a kako bi, između ostalog, ispitali je li nacionalno tijelo koje je izdalo dozvolu za projekt koji može imati utjecaja na stanje vode ispunilo svoje obveze iz članka 4. Direktive, a osobito sprječavanje pogoršanja vodnih tijela, te da se zadržalo u granicama slobodne procjene koju je nadležnim državnim tijelima dodijelila ta odredba. ${ }^{65}$

Osim odredbe članka 9. stavka 3. Aarhuške konvencije koji se odnosi na osiguravanje pristupa pravosuđu kada se određenim odlukama, radnjama ili propustima krše propisi koji se odnose na okoliš, Sud EU-a utvrdio je da se na ovaj predmet primjenjuje i Povelja EU-a o temeljnim pravima, ${ }^{66}$ koja u svom članku 47. jamči pravo na djelotvorni pravni lijek i na pošteno suđenje. ${ }^{67}$ Prema pravnom shvaćanju Suda, odredba članka 9. stavka 3. Konvencije, u vezi s člankom 47. Povelje, nameće državama članicama obvezu osiguranja učinkovite sudske zaštite prava koja proizlaze iz prava Europske unije, a posebice iz odredaba prava okoliša ${ }^{68} \mathrm{~S}$ obzirom na važnost toga dijela presude, koja još nije prevedena na hrvatski jezik, citirat će se njezin dio u cijelosti:

"45. Istina je da samo "članovi javnosti» koji "udovoljavaju mjerilima, ako ih ima, utvrđenima domaćim zakonodavstvom" imaju prava iz članka 9. stavka 3.

63 V. presuda Suda EU-a C-664/15, op. cit. (bilj. 29), točka 32.

64 Ibid., točka 34.

65 Ibid.

66 SL C 202, 7.6.2016., str. 389.

67 Presuda Suda EU-a C-664/15, op. cit. (bilj. 29), točka 44.

68 Ibid., točka 45. 
Aarhuške konvencije, tako da ta odredba, sama po sebi, nema izravni učinak u pravu EU-a. Međutim, ostaje činjenica da ta odredba, u vezi s člankom 47. Povelje, nameće državama članicama obvezu osiguranja učinkovite sudske zaštite prava koja proizlaze iz prava Europske unije, a osobito iz odredbama prava okoliša (vidi, u tom smislu, presudu od 8. ožujka 2011., Lesoochranárske zoskupenie, C-240/09, EU:C:2011:125, točke 45. i 51.).

46. Kao što je nezavisna odvjetnica napomenula, u suštini, u točkama 89. i 90. njezinog Mišljenja, pravo na pokretanje postupka iz članka 9. stavka 3. Aarhuške konvencije bilo bi lišeno svog korisnog djelovanja, pa čak i svoje same biti, ako bi se trebalo priznati da je, određivanjem tih uvjeta, određenim kategorijama "pripadnika javnosti", a tim više "zainteresiranoj javnosti", poput organizacija za zaštitu okoliša koje zadovoljavaju uvjete iz članka 2. točke 5. Aarhuške konvencije, uskraćeno bilo kakvo pravo na pokretanje postupka.

47. Utvrđivanje tih kriterija ne smije lišiti organizacije za zaštitu okoliša, osobito, mogućnosti provjere poštuju li se pravila prava okoliša EU-a, s obzirom na to da su takva pravila obično u javnom interesu, a ne samo u interesu pojedinih pojedinaca, te da je cilj tih organizacija braniti javni interes (vidi, u tom smislu, presudu od 12 . svibnja 2011. godine Bund für Umwelt und Naturschutz Deutschland, Landesverband Nordrhein-Westfalen, C-115/09, EU:C:2011:289, točka 46.).

48. Iako podrazumijevaju da država ugovornica zadržava diskreciju glede provedbe te odredbe, riječi "mjerilima, ako ih ima, utvrđenima domaćim zakonodavstvom" u članku 9. stavku 3. Aarhuške konvencije ne mogu dopustiti tim državama da nametnu kriterije tako strogo da bi za organizacije za zaštitu okoliša bilo praktično nemoguće osporavati radnje ili propuste na koje se te odredbe primjenjuju." ${ }^{\circ 9}$

Prema austrijskom pravu, samo fizičke ili pravne osobe koje su stranke upravnog postupka mogu podnijeti tužbu sudu radi zaštite svojih prava za koja tvrde da su im povrijeđena. Organizacije za zaštitu okoliša koje nemaju nikakva subjektivna javna prava nemaju položaj stranke u postupku izdavanja odobrenja za vađenje vode na temelju austrijskoga Zakona o vodama. Stoga, uskraćujući organizacijama za zaštitu okoliša prava da podnesu tužbu protiv takve odluke o izdavanju odobrenja, relevantno nacionalno postupovno pravo suprotno je zahtjevima koji proizlaze iz zajedničke primjene članka 9. stavka 3. Aarhuške konvencije i članka 47. Povelje. ${ }^{70} \mathrm{U}$ tom slučaju, nacionalni sud dužan je uskratiti primjenu nacionalne norme koja je protivna odredbama prava EU-a, čak i ako prema svom nacionalnom pravu nema uopće tu ovlast ili bi morao zastati s postupkom i čekati da tu normu ukine neko drugo tijelo, primjerice, Ustavni sud. ${ }^{71}$

S obzirom na sve prethodno navedeno, Sud EU-a odgovorio je na prvo pitanje da se članak 9. stavak 3. Aarhuške konvencije, u svezi s člankom 47. Povelje o temeljnim pravima, mora tumačiti tako da pravilno osnovana organizacija za zaštitu okoliša koja djeluje sukladno zahtjevima nacionalnog prava mora biti u mogućnosti podnijeti tužbu pred sudom protiv odluke kojom se odobrava odobrenje za projekt

69 Presuda Suda EU-a C-664/15, op. cit. (bilj. 29), točke 45-48.

70 Ibid., točka 52.

71 Ibid., točka 56. 
koji može biti u suprotnosti s obvezom sprečavanja pogoršanja stanja vodnih tijela koja je propisana člankom 4. Okvirne direktive o vodama. ${ }^{72}$

Drugo pitanje koje je postavio Visoki upravni sud glasilo je: Zahtijeva li se, u skladu s odredbama Aarhuške konvencije, da se prava koja proizlaze iz Okvirne direktive o vodama mogu ostvariti već u postupku pred upravnim tijelom ili je dovoljna mogućnost pružanja sudske zaštite protiv odluke upravnog tijela?

Prema članku 14. stavku 1. Okvirne direktive o vodama, države članice su dužne poticati aktivno uključivanje svih zainteresiranih strana u provedbu Okvirne direktive o vodama, a posebno u izradu, preispitivanje i nadopunjavanje planova upravljanja riječnim slivovima. Međutim, kako to pojašnjava Sud EU-a riječ "poticati" donekle izražava aspiraciju, tako da je obvezujuća priroda te odredbe ograničena. To potvrđuje i činjenica da, iako druge odredbe članka 14. sadrže prave obveze, one se posebno odnose na postupak izrade, preispitivanja i nadopunjavanja planova upravljanja riječnim slivom. ${ }^{73}$ Međutim, činjenica ostaje da kada primjenjuju Okvirnu direktivu o vodama, države članice su dužne poštovati bit članka 14. stavka 1. koji se sastoji od obveze poticanja svih zainteresiranih strana da aktivno sudjeluju u njezinoj provedbi. ${ }^{74}$

Nije sporno da je Protect imao mogućnost, u određenoj mjeri, sudjelovati u postupku u svojstvu "zainteresirane strane" u smislu WRG-a. Međutim, položaj "zainteresirane strane" nije jednak položaju stranke u upravnom postupku. ${ }^{75}$ Položaj stranke u upravnom postupku omogućuje organizaciji za zaštitu okoliša aktivno sudjeluje u odlučivanju, tako da detaljnije i na prikladniji način izloži svoje argumente o riziku da bi planirani projekt mogao imati štetne učinke na okoliš. Nadležna tijela moraju te argumente uzeti u obzir prije nego što odobre projekt. ${ }^{76}$

Prema mišljenju Suda EU-a: "Aktivno sudjelovanje Protect-a kao pravilno osnovane organizacije za zaštitu okoliša koja djeluje u skladu sa zahtjevima primjenjivog nacionalnog prava je još važnije, s obzirom na to da su samo takve organizacije orijentirane prema javnom interesu, a ne zaštiti interesa pojedinaca". ${ }^{77}$

S obzirom na sve naprijed navedeno, odgovor Suda EU-a na drugo pitanje je da se odredbe članka 9. stavka 3. Aarhuške konvencije, članka 47. Povelje i članka 14. stavka 1. Direktive 2000/60, moraju tumačiti tako da im se protive nacionalna postupovna pravila koja oduzimaju organizacijama za zaštitu okoliša pravo sudjelovanja kao stranke u postupku izdavanja odobrenja koje je namijenjeno provedbi Okvirne direktive o vodama i koja ograničavaju pravo pokretanja postupaka osporavanja odluka donesenih u takvom postupku isključivo na osobe koje imaju takav položaj. ${ }^{78}$

Drugim riječima, organizacijama za zaštitu okoliša, poput Protecta, mora se omogućiti pravo da kao stranke sudjeluju u postupcima za izdavanje odobrenja koja se vode na temelju odredaba nacionalnog prava kojima je provedena Okvirna direktiva o vodama. 
I na kraju, treće pitanje koje je postavio Visoki upravni sud glasilo je: Je li dopuštena odredba nacionalnoga postupovnog prava (članak 42. Zakona o općem upravnom postupku) kojom se nalaže da organizacija za zaštitu okoliša, kao i druge stranke postupka, svoje prigovore mora pravodobno istaknuti već u postupku pred upravnim tijelima, a ne tek u tužbi podnesenoj upravnom sudu, jer u protivnome gubi položaj stranke i ne može više podnijeti tužbu upravnom sudu? Sud EU-a odgovorio je da se članci 9. stavci 3. i 4. Aarhuške konvencije u vezi s člankom 47. Povelje Europske unije o temeljnim pravima, trebaju tumačiti na način da im se protive nacionalna postupovna pravila koja postavljaju rok organizaciji za zaštitu okoliša kojim ona gubi položaj stranke i stoga ne može protiv odluke donesene u tom postupku podnijeti tužbu, ako nije istaknula pravodobno prigovore, nakon pokretanja postupka, ili najkasnije, tijekom usmene rasprave u tom postupku. ${ }^{79}$

Kakav učinak ova presuda ima na mnoge države članice EU-a, ne samo na Austriju? Države u kojima udruge za zaštitu okoliša nemaju pravo sudjelovati u postupcima izdavanja vodopravnih akata, kao što je to i Hrvatska, nisu usklađene s Okvirnom direktivom o vodama.

Prema članku 141. stavku 2. hrvatskoga Zakona o vodama, vodopravni akti izdaju se radi postizanja utvrđenih ciljeva upravljanja vodama iz članka 4. tog Zakona koji uključuju i "postizanje i očuvanje dobrog stanja voda radi zaštite života i zdravlja ljudi, zaštite njihove imovine, zaštite vodnih i o vodi ovisnih ekosustava". Kao što je to već spomenuto u poglavlju 2.2. ovoga rada, hrvatski zakonodavac propisao je da javnost ima pravo sudjelovati samo u izradi planskih dokumenata za upravljanje vodama (čl. 5. st. 8. ZV-a). To znači da hrvatski Zakon o vodama nije usklađen s člamkom 14. stavkom 1. Okvirne direktivom o vodama, Aarhuškom konvencijom i člankom 47. Povelje o temeljnim pravima.

Udrugama za zaštitu okoliša koje djeluju u javnom interesu mora se omogućiti položaj stranke u tim postupcima. Osim toga, udruge za zaštitu okoliša moraju imati pravo osporavati vodopravne akte ako smatraju da su njima povrijeđene odredbe domaćega zakonodavstva iz područja zaštite okoliša, što uključuje i pravo okoliša Europske unije.

\subsection{Pogrešna provedba članka 9. stavka 3. Aarhuške konvencije u hr- vatsko zakonodavstvo}

U Hrvatskoj je članak 9. stavak 3. Aarhuške konvencije ${ }^{80}$ neispravno proveden u Zakon o zaštiti okoliša (dalje i: ZoZO). ${ }^{81}$

Članak 19. stavak 2. ZoZO-a propisuje: "U svrhu zaštite prava na zdrav život i održiv okoliš te u svrhu zaštite okoliša i pojedinih sastavnica okoliša i zaštite od

79 Ibid., točka 101.

80 Čl. 9. st. 3. glasi: "3. Osim i bez obzira na postupke ocjene navedene u stavcima 1. i 2. ovoga članka, svaka je stranka dužna osigurati pripadnicima javnosti, koji udovoljavaju mjerilima, ako ih ima, utvrđenima domaćim zakonodavstvom, pristup administrativnim ili sudbenim postupcima kojima se osporavaju činjenja i nečinjenja privatnih osoba i tijela vlasti koji su u suprotnosti s odredbama domaćega zakonodavstva koje se odnose na okoliš."

81 Narodne novine br. 80/2013, 153/2013, 78/2015. 
štetnog utjecaja opterećenja, osoba koja učini vjerojatnim svoj pravni interes i osoba koja zbog lokacije zahvata i/ili zbog prirode i/ili utjecaja zahvata može, u skladu sa zakonom, dokazati da joj je trajno narušeno pravo (istaknula autorica), ima pravo osporavati postupovnu i materijalnu zakonitost odluka, čina i propusta tijela javne vlasti putem nadležnog tijela i/ili nadležnog suda, u skladu sa zakonom."

Ovom odredbom, kao jednim od načela zaštite okoliša, utvrđeno je načelo prava na pristup pravosuđu. To načelo sadrži uvjet "trajnog narušavanja prava" koje nije u skladu s Aarhuškom konvencijom ni Direktivom 2003/35. ${ }^{82}$ Ne postoji niti jedan drugi primjer u hrvatskom zakonodavstvu da je trajna povreda prava uvjet za dopuštenost podnošenja tužbe u upravnom sporu. Dovoljno je da tužitelj smatra da mu je pravo povrijeđeno. Povreda ne mora biti trajna. Osim što je ovaj uvjet "trajnog narušavanja prava" protivan članku 9. stavku 2. Aarhuške konvencije, on je protivan i Ustavu Republike Hrvatske, ${ }^{83}$ jer nerazmjerno ograničava pravo na pristup sudu te sudsku kontrolu pojedinačnih akata upravnih vlasti i tijela koja imaju javne ovlasti (članak 29. stavak 1. te članak 19. stavak 2. Ustava RH). Ova odredba vjerojatno je nastala kao posljedica pogrešnog prijevoda članka 10.a Direktive 2003/35 na hrvatski jezik. ${ }^{84}$ No, to nikako ne ispričava pogrešni prijenos Aarhuške konvencije i Direktive 2003/35 koji je zakonodavac počinio u tekstu Zakona o zaštiti okoliša iz 2007..$^{85}$ (v. članak 18. stavak $2 .{ }^{86}$ te članak 144. stavak $1 .{ }^{87}$ Zakona iz 2007.). Tu je pogrešku zakonodavac u novom Zakonu o zaštiti okoliša iz 2013. samo djelomično ispravio na način da je

82 Direktiva 2003/35/EZ Europskog parlamenta i Vijeća od 26. svibnja 2003. o osiguravanju sudjelovanja javnosti u izradi određenih planova i programa koji se odnose na okoliš i o izmjeni direktiva Vijeća 85/337/EEZ i 96/61/EZ s obzirom na sudjelovanje javnosti i pristup pravosuđu, SL L 156, 25.6.2003, str. 17.

83 Ustav Republike Hrvatske, Narodne novine, br. 56/1990, 135/1997, 8/1998 - pročišćeni tekst, 113/2000, 124/2000 - pročišćeni tekst, 28/2001, 41/2001 - pročišćeni tekst, 55/2001 - ispravak, 76/2010, 85/2010 - pročišćeni tekst, 5/2014.

84 Radna verzija prijevoda Direktive 2003/35 na hrvatski jezik bila je dostupna na web stranici http://www.prevodi.gov.me/15.10.10/32003L0035.pdf, međutim pristup toj stranici više nije moguć. Relevantni dio pogrešnog prijevoda je glasio: "Države članice osigurat će da se, sukladno odgovarajućem nacionalnom pravnom sustavu, članovima zainteresirane javnosti: (a) koji imaju dovoljan interes ili (b) koji trajno narušavaju pravo (istaknula autorica), u slučaju da upravno postupovno pravo države članice to propisuje kao preduvjet, omogući pristup ispitivanju pred sudom ili nekim drugim nezavisnim i nepristranim tijelom koje je određeno zakonom radi pobijanja materijalne ili postupovne zakonitosti odluka, radnji ili propusta, sukladno odredbama ove Direktive koje se odnose na sudjelovanje javnosti."

85 Narodne novine, br. 110/2007.

86 "U svrhu zaštite prava na zdrav život i održiv okoliš te u svrhu zaštite okoliša i pojedinih sastavnica okoliša i zaštite od štetnog utjecaja opterećenja, osoba (građanin i druga fizička te pravna osoba, njihove skupine, udruge i organizacije) koja učini vjerojatnim svoj pravni interes i osoba koja zbog lokacije zahvata i/ili zbog prirode i/ili utjecaja zahvata može, u skladu sa zakonom, dokazati da joj je trajno narušeno pravo, ima pravo osporavati postupovnu i materijalnu zakonitost odluka, čina i propusta tijela javne vlasti putem nadležnog tijela i/ili nadležnog suda, u skladu sa zakonom.”

87 "Da ima vjerojatan pravni interes u postupcima uređenim ovim Zakonom u kojima je predviđeno sudjelovanje zainteresirane javnosti smatrat će se svaka fizička i pravna osoba koja zbog lokacije zahvata i/ili zbog prirode i utjecaja zahvata može, u skladu sa zakonom, dokazati da joj je trajno narušeno pravo." 
izbacio riječ "trajno" iz članka 167. stavka 1. (koji je u svemu ostalome identičan članku 144. stavku 1. Zakona iz 2007.). Međutim, uvjet trajnog narušavanja prava zadržan je u odredbi članka 19. stavak 2. Zakona o zaštiti okoliša, kojom se utvrđuje načelo prava na pristup pravosuđu, što tu odredbu čini protivnom Direktivi 2003/35, Aarhuškoj konvenciji te Ustavu.

Ispravan prijevod Direktive 2003/35 u međuvremenu je objavljen u Službenom listu Europske unije. ${ }^{88}$ Zakonodavac bi trebao uzeti u obzir prijevod članka 10.a Direktive 2003/35 $5^{89}$ te ispraviti odredbu ZoZO-a, koja je vjerojatno nastala kao rezultat pogrešnog prijevoda. Također, načelo prava na pristup pravosuđu trebalo bi uskladiti sa Zakonom o upravnim sporovima (dalje i: ZUS) ${ }^{90}$ kako bi se očuvala konzistentnost hrvatskoga pravnog sustava. Budući da upravno postupovno pravo Republike Hrvatske propisuje da pravo podnošenja tužbe ima svatko tko smatra da mu je povrijeđeno pravo ili pravni interes, ${ }^{91}$ takva odredba trebala bi biti sadržana i u načelu prava na pristup pravosuđu.

U tom smislu članak 19. stavak 2. ZoZO-a (usklađen s Direktivom 2003/35 te Zakonom o upravnim sporovima) trebao bi glasiti: "U svrhu zaštite prava na zdrav život i održiv okoliš te u svrhu zaštite okoliša i pojedinih sastavnica okoliša i zaštite od štetnog utjecaja opterećenja, osoba koja učini vjerojatnim svoj pravni interes ili koja zbog lokacije zahvata $\mathrm{i} / \mathrm{ili}$ zbog prirode $\mathrm{i} / \mathrm{ili}$ utjecaja zahvata smatra da joj je povrijeđeno pravo ili pravni interes, ima pravo osporavati postupovnu i materijalnu zakonitost odluka, radnji i propusta tijela javne vlasti putem nadležnog tijela i/ili nadležnog suda, u skladu sa zakonom."

Za daljnju ocjenu usklađenosti s člankom 9. stavkom 3. Aarhuške konvencije nužno je citirati odredbe članka 167. i članka 169. ZoZO-a koje su prikazane u tablici 3.

88 V. Posebno izdanje na hrvatskom jeziku: Poglavlje 15., sv. 026., str. 48.

89 Relevantni dio glasi: "Članak 10.a.

Države članice osiguravaju da u skladu s odgovarajućim nacionalnim pravnim sustavom, pripadnici zainteresirane javnosti:

(a) koji imaju dovoljan interes ili, alternativno,

(b) koji tvrde da im je povrijeđeno pravo, ako upravno postupovno pravo države članice to propisuje kao preduvjet (istaknula autorica), imaju pristup postupku revizije pred sudom ili nekim drugim nezavisnim i nepristranim tijelom koje je određeno pravom radi pobijanja materijalne ili postupovne zakonitosti odluka, radnji ili propusta, u skladu s odredbama ove Direktive koje se odnose na sudjelovanje javnosti..."

90 Narodne novine, br. 20/2010, 143/2012, 152/2014, 94/2016 - Odluka Ustavnog suda i 29/2017.

91 Članak 17. stavak 1. ZUS-a glasi: "Tužitelj je fizička ili pravna osoba koja smatra da su joj prava i pravni interesi povrijeđeni pojedinačnom odlukom, postupanjem javnopravnog tijela, odnosno propuštanjem donošenja pojedinačne odluke ili postupanja javnopravnog tijela u zakonom propisanom roku ili sklapanjem, raskidom ili izvršavanjem upravnog ugovora." 
Tablica 3. Osporavanje odluka, radnji i propusta tijela javne vlasti u pitanjima zaštite okoliša

\begin{tabular}{|c|c|}
\hline $\begin{array}{l}\text { Priznavanje pravnog interesa osobama } \\
\text { zainteresirane javnosti } \\
\text { Članak 167. ZoZO-a }\end{array}$ & $\begin{array}{c}\text { Osporavanje odluka, radnji i propusta tijela javne } \\
\text { vlasti te djelovanja ili propuštanja djelovanja } \\
\text { pravnih i fizičkih osoba u pitanjima zaštite okoliša } \\
\text { Članak } 169 \text {. ZoZO-a }\end{array}$ \\
\hline $\begin{array}{l}\text { (1) Da ima vjerojatan pravni interes u } \\
\text { postupcima uređenim ovim Zakonom } \\
\text { u kojima je predviđeno sudjelovanje } \\
\text { zainteresirane javnosti smatrat će se svaka } \\
\text { fizička i pravna osoba koja zbog lokacije } \\
\text { zahvata i/ili zbog prirode i utjecaja } \\
\text { zahvata može, u skladu sa zakonom, } \\
\text { dokazati da joj je narušeno pravo. } \\
\text { (2) Podrazumijeva se da ima dovoljan } \\
\text { (vjerojatan) pravni interes u postupcima } \\
\text { uređenim ovim Zakonom u kojima je } \\
\text { predviđeno sudjelovanje zainteresirane } \\
\text { javnosti i udruga civilnog društva koja } \\
\text { djeluje na području zaštite okoliša ako: } \\
\text { - je registrirana sukladno posebnim } \\
\text { propisima o udrugama te da joj je statutom } \\
\text { kao cilj određena zaštita i unaprjeđenje } \\
\text { okoliša, uključujući i zaštitu ljudskog } \\
\text { zdravlja i zaštitu ili racionalno korištenje } \\
\text { prirodnih dobara, } \\
\text { - je registrirana u smislu podstavka } 1 . \\
\text { ovoga stavka najmanje dvije godine } \\
\text { prije nego je započeo postupak tijela } \\
\text { javne vlasti o zahtjevu povodom kojega } \\
\text { iskazuje svoj pravni interes, te ako dokaže } \\
\text { da je u tom razdoblju aktivno sudjelovala } \\
\text { u aktivnostima vezanim za zaštitu okoliša } \\
\text { na području grada ili općine gdje ima } \\
\text { registrirano sjedište sukladno svojem } \\
\text { statutu. }\end{array}$ & $\begin{array}{l}\text { (1) Fizička i pravna osoba koja ispunjava uvjete iz } \\
\text { članka 167. stavka 1. ovoga Zakona i smatra da je } \\
\text { odlukom, radnjom i propustom tijela javne vlasti ili } \\
\text { djelovanjem ili propuštanjem djelovanja fizičke ili } \\
\text { pravne osobe (primjerice: operatera, onečišivača) } \\
\text { u pitanjima zaštite okoliša povrijeđen ovaj Zakon, } \\
\text { odnosno posebni zakon kojim je uređena zaštita } \\
\text { pojedine sastavnice okoliša ili zaštita od utjecaja } \\
\text { opterećenja, te propisi doneseni na temelju tih } \\
\text { zakona, imaju pravo, pred nadležnim sudom } \\
\text { sukladno ovom Zakonu i posebnim propisima } \\
\text { osporavati zakonitost donesene odluke, radnje i } \\
\text { propusta u vezi sa zaštitom okoliša, te osporavati } \\
\text { zakonitost djelovanja ili propuštanja djelovanja u } \\
\text { pitanjima zaštite okoliša. } \\
\text { (2) Zahtjev u smislu stavaka } 1 \text {. ovoga članka } \\
\text { mora biti podnesen u propisanom obliku sukladno } \\
\text { posebnom propisu, u roku od } 30 \text { dana od dana } \\
\text { dostave strankama, odnosno dana objave na } \\
\text { internetskim stranicama tijela koje je donijelo } \\
\text { odluku koja se osporava, odnosno od dana proteka } \\
\text { roka za izvršenje radnje odnosno donošenje odluke. } \\
\text { U zahtjevu mora biti navedeno i obrazloženo u } \\
\text { čemu je sadržana odnosno na što se odnosi povreda } \\
\text { propisa iz stavka } 1 \text { ovoga članka. Zahtjev mora biti } \\
\text { potkrijepljen odgovarajućim dokazima. }\end{array}$ \\
\hline
\end{tabular}

Svrha je članka 9. stavka 3. Aarhuške konvencije omogućiti javnosti pravna sredstva kojima će se postići provedba važećih odredaba zakona koje se odnose na okoliš. Stranke Konvencije ne moraju uvesti actio popularis, ali uvjeti za osporavanje odluka, radnji i propusta ne smiju biti toliko rigorozni da praktički onemogućavaju svim udrugama za zaštitu okoliša i većini drugih subjekata pristup pravosuđu temeljem članka 9. stavka 3. Pristup mora biti pravilo, a ne iznimka.

Premda je, kao što je već prethodno napomenuto, iz odredbe članka 167. stavka 1. zakonodavac izbacio riječ "trajno", svejedno se i dalje dovodi u nejednaki položaj tužitelj, koji pristup upravnosudskoj kontroli ostvaruje temeljem ZUS-a i onaj koji pristup toj kontroli ostvaruje primjenom ZoZO-a, što je protivno članku 14. stavku 
2. Ustava koji jamči jednakost svih pred zakonom. Naime, sukladno ZUS-u tužitelj je fizička ili pravna osoba koja smatra da su joj prava i pravni interesi povrijeđeni pojedinačnom odlukom, postupanjem javnopravnoga tijela, odnosno propuštanjem donošenja pojedinačne odluke ili postupanja javnopravnoga tijela u zakonom propisanom roku. Sukladno članku 167. stavka 1. tužitelj je osoba koja zbog lokacije zahvata i/ili zbog prirode i utjecaja zahvata može, u skladu sa zakonom, dokazati da joj je narušeno pravo. Ne postoji razumno opravdanje za takav nejednak pristup gdje se u ZoZO-u pravo na podnošenje tužbe veže uz dokazivanje povrede prava umjesto uz tvrdnju, tj. mišljenje da su prava i pravni interesi povrijeđeni.

Nadalje, odredba članka 169. stavka 1. nije u skladu s Arhuškom konvencijom jer udruge za zaštitu okoliša u pravilu neće moći dokazati da im je narušeno pravo, budući da one većinom djeluju radi zaštite općih interesa, a ne vlastitih. Upravo je takvim organizacija, prema presudi Suda EU-a u predmetu Protect potrebno osigurati mogućnost podnošenja tužbe, sukladno članku 9. stavku 3. Aarhuške konvencije.

U odredbi članka 169. stavak 1 . ZZO-a nije propisano o kojem je nadležnom sudu riječ, već je to pitanje prepušteno posebnim propisima. Da bi neka osoba mogla ostvariti pravo na podnošenje tužbe nadležnom sudu moraju se ispuniti, ne samo uvjeti određeni ZoZO-om, već i uvjeti određeni tim posebnim propisima. Takav zaključak mogao bi proizlaziti iz dijela odredbe članka 169. stavka 1. koji propisuje da osobe "imaju pravo, pred nadležnim sudom sukladno ovom Zakonu i posebnim propisima osporavati postupovnu i materijalnu zakonitost donesene odluke, radnje i propusta $u$ vezi sa zaštitom okoliša" (istaknula autorica).

Svrha je Konvencije da se omogući širi pristup pravosuđu u pitanjima okoliša. Osnovno polazište je da, ako postojeće zakonodavstvo ne osigurava široki pristup pravosuđu, morat će se prilagoditi Arhuškoj konvenciji. Odredbom članka 169. stavka 1. uvedeni su dvostruki uvjeti za osporavanje postupovne i materijalne zakonitosti donesene odluke, radnje i propusta u vezi sa zaštitom okoliša - novi uvjeti propisani ZoZO-om, a da su pritom zadržani uvjeti koji su propisani posebnim zakonima. Time je zapravo sužen pristup pravosuđu.

U pogledu roka, propisano je da zahtjev nadležnom sudu mora biti podnesen u roku od 30 dana od dana dostave strankama, odnosno dana objave na internetskim stranicama tijela koje je donijelo odluku koja se osporava, odnosno od dana proteka roka za izvršenje radnje odnosno donošenje odluke.

Budući da se brojni upravni akti (poput vodopravnih akata), kojima može doći do povrede odredaba posebnih zakona i podzakonskih propisa vezanih za zaštitu okoliša, javno ne objavljuju (čak štoviše ne objavljuju se ni informacije da se provode konkretni postupci), niti u postupcima njihovog donošenja pripadnici zainteresirane javnosti imaju pravo sudjelovati, podnošenje tužbi protiv takvih akata svedeno je na iluzorno pravo. To je i razlog zašto se u praksi sporovi temeljem članka 169. Zakona o zaštiti okoliša uopće ne pokreću.

Osim toga, ako odluka nije donesena, odnosno da javnopravno tijelo nije postupilo u zakonom propisanom roku, prema ZUS-u ne postoje "krajnji" rokovi za podnošenje pravnog sredstva. Tužba jedino može biti prijevremena, ako stranka nije čekala da protekne zakonom propisani rok u kojem je javnopravno tijelo trebalo 
donijeti i dostaviti stranci odluku ili na neki drugi način postupiti. ${ }^{92}$ Međutim, čim taj rok protekne, pravno sredstvo se ne može smatrati nepravovremenim, ako povreda zakonske obveze donošenja odluke odnosno postupanja još uvijek traje. ${ }^{93}$

I na posljetku, rok od 30 dana koji se odnosi na propust javnopravnih tijela nerazumno je kratak. Kako neka osoba uopće može znati kada je istekao rok da javnopravno tijelo nešto poduzme po zakonu u postupku u kojem ona uopće nije stranka, niti u tom postupku ima pravo sudjelovati, pa da bi onda u narednih 30 dana mogla podnijeti tužbu koja povrh toga mora biti potkrijepljena odgovarajućim dokazima. Uostalom, kao što je već prethodno rečeno, takva tužba jedino bi mogla biti prijevremena (ako se nije čekalo osam dana nakon proteka propisanog roka), a ne i zakašnjela, jer je opće pravilo prema ZUS-u da se u slučaju propusta tužba može podnijeti sve dok povreda zakonske obveze postupanja još uvijek traje.

Zbog svih navedenih razloga hrvatski zakonodavac trebao bi uskladiti odredbu članka 169. stavka 2. s pretpostavkama i rokovima za podnošenje tužbe koji vrijede prema ZUS-u. Osim toga, morao bi omogućiti i udrugama za zaštitu okoliša pravo podnošenja tužbe, kao što im je to i inače dopušteno u postupcima uređenima ZoZOom.

\section{ZAKLJUČAK}

U presudi C-461/13 Weser Sud Europske unije utvrdio je da su okolišni ciljevi Okvirne direktive o vodama pravno obvezujući. Ne radi se samo o političkim težnjama čije je ostvarenje podložno najboljim nastojanjima država članica. To znači, da čak i ako neki zahvat ispunjava sve uvjete temeljem drugih mjerodavnih propisa, ako će se zbog njegove provedbe pogoršati stanje površinskih voda, tada se ne smije izdati odobrenje za provedbu projekta, osim ako su ispunjeni uvjeti za primjenu iznimki. U tom smislu, moguće je da će praktična posljedica ove presude biti ta da će se u državama članicama sve češće početi koristiti iznimke propisane u članku 4. stavku 7. Okvirne direktive o vodama. Zbog toga će se morati bolje urediti postupci u kojima se o tim iznimkama odlučuje te će se morati omogućiti sudjelovanje zainteresirane javnosti, osobito udruga za zaštitu okoliša. Hrvatski Zakon o vodama u tom pogledu nije usklađen s Okvirnom direktivom o vodama jer sudjelovanje zainteresirane javnosti omogućava samo u izradi planskih dokumenata za upravljanje vodama, ali ne i pri izdavanju vodopravnih akata.

O sudjelovanju zainteresirane javnosti bila je riječ u presudi C-644/15 Protect. Udrugama za zaštitu okoliša mora se omogućiti sudjelovanje u postupcima izdavanja upravnih akata koji se pokreću sa svrhom provedbe Okvirne direktive o vodama. Izdavanje vodopravnih akata prema hrvatskom Zakonu o vodama upravo se provodi radi postizanja i očuvanja dobrog stanja voda (v. čl. 141. st. 1. u vezi s čl. 4. st. 2. t. 2. ZV-a). Uz to, učinkovitost Okvirne direktive o vodama i njezin cilj zaštite okoliša

92 Pri pokretanju spora zbog propuštanja donošenja pojedinačne odluke ili propuštanja postupanja u propisanom roku tužba se sudu podnosi najranije osam dana nakon proteka propisanog roka (čl. 24. st. 2. ZUS-a).

93 V. Borković, I., Upravno pravo, Narodne novine, Zagreb, 2002., str. 524. 
zahtijevaju da se pripadnici zainteresirane javnosti mogu osloniti na nju u sudskim postupcima. Odredba članka 9. stavka 3. Aarhuške konvencije koja se odnosi na pravo na pristup pravosuđu nameće državama članicama obvezu osiguranja učinkovite sudske zaštite prava koja proizlaze iz prava EU-a, a osobito iz odredaba prava okoliša. Nažalost, način na koji je članak 9. stavak 3. proveden u hrvatsko zakonodavstvo postavlja pojedincima uvjete koje je nemoguće ispuniti, a osim toga udruge za zaštitu okoliša lišava prava da pokreću upravne sporove. Postupak izdavanja vodopravnih akata u Hrvatskoj trebao bi se reformirati na način da se uskladi s Okvirnom direktivom o vodama i Aarhuškom konvencijom te relevantnim presudama Suda EU-a. 


\section{LITERATURA}

1. Alge, T. i dr., Priručnik o načinu određivanja statusa voda i provedbi monitoringa, Zelena akcija, Zagreb, 2012.

2. Borković, I., Upravno pravo, Narodne novine, Zagreb, 2002.

3. European Commission, Commission Staff Working Document, Part I: Policy areas, Accompanying the document, Monitoring the application of European Union law, 2016 Annual Report, Brussels, 6.7.2017, SWD(2017) 259 final.

4. Europska agencija za okoliš, Europsko izvješće o okolišu - stanje i izgledi 2015.: sinteza, 2015.

5. Europska komisija, Izvješće Komisije - Praćenje primjene zakonodavstva Europske unije, Godišnje izvješće za 2016., Bruxelles, 6.7.2017., COM/2017/0370 final.

6. Farmer, A. M. (ur.), Manual of European Environmental Policy, Routledge, London, 2012.

7. Grimeaud, D., Reforming EU Water Law: Towards Sustainability?, European Environmental Law Review, vol. 10, br. 2, 2001., str. 41.-51.

8. Jans, J. H., Vedder, H. H. B., European Environmental Law - After Lisbon, 4th ed., Europa Law Publishing, Groningen, 2012.

9. Paloniity, T., The Weser Case: Case C-461/13 Bund v Germany, Journal of Environmental Law, 2016., 28, str. 151.-158.

10. Vanheudsen, B., Squintani, L. (eds.), EU Environmental and Planning Law Aspects of Large-Scale Projects, Cambridge, Intersentia, 2016.

Pravni izvori

1. Council Decision of 17 February 2005 on the conclusion, on behalf of the European Community, of the Convention on access to information, public participation in decision-making and access to justice in environmental matters (2005/370/EC), SL L 124, 17.05.2005., str. 1.

2. Direktiva 2000/60/EZ Europskog parlamenta i Vijeća od 23. listopada 2000. o uspostavi okvira za djelovanje Zajednice u području vodne politike, SL L 327, 22.12.2000., str. 1., Posebno izdanje na hrvatskom jeziku: Poglavlje 15., sv. 001., str. 48.

3. Direktiva 2003/35/EZ Europskog parlamenta i Vijeća od 26. svibnja 2003. o osiguravanju sudjelovanja javnosti u izradi određenih planova i programa koji se odnose na okoliš i o izmjeni direktiva Vijeća 85/337/EEZ i 96/61/EZ s obzirom na sudjelovanje javnosti i pristup pravosuđu, SL L 156, 25.6.2003., str. 17., Posebno izdanje na hrvatskom jeziku: Poglavlje 15., sv. 026., str. 48.

4. Direktiva 2004/35/EZ Europskog parlamenta i Vijeća od 21. travnja 2004. o odgovornosti za okoliš u pogledu sprečavanja i otklanjanja štete u okolišu, SL L 143, 30.4.2004., str. 56, Posebno izdanje na hrvatskom jeziku: Poglavlje 15., sv. 026., str. 58.

5. Direktiva 2006/118/EZ Europskog parlamenta i Vijeća od 12. prosinca 2006. o zaštiti podzemnih voda od onečišćenja i pogoršanja stanja, SL L 372, 27.12.2006., str. 19, Posebno izdanje na hrvatskom jeziku: Poglavlje 15., sv. 028., str. 41.

6. Direktiva 2006/7/EZ Europskog parlamenta i Vijeća od 15. veljače 2006. o upravljanju kvalitetom vode za kupanje i stavljanju izvan snage Direktive 76/160/EEZ, SL L 64, 4.3.2006., str. 37, Posebno izdanje na hrvatskom jeziku: Poglavlje 15., sv. 006., str. 179.

7. Direktiva 2007/60/EZ Europskog parlamenta i Vijeća od 23. listopada 2007. o procjeni i upravljanju rizicima od poplava, SL L 288, 6.11.2007., str. 27., Posebno izdanje na hrvatskom jeziku: Poglavlje 15., sv. 001., str. 186.

8. Direktiva 2008/105/EZ Europskog parlamenta i Vijeća od 16. prosinca 2008. o standardima kvalitete okoliša u području vodne politike i o izmjeni i kasnijem stavljanju izvan snage Direktiva Vijeća 82/176/EEZ, 83/513/EEZ, 84/156/EEZ, 84/491/EEZ, 
86/280EEZ i izmjeni Direktive 2000/60/EZ Europskog parlamenta i Vijeća, SL L 348, 24.12.2008., str. 84., Posebno izdanje na hrvatskom jeziku: Poglavlje 15., sv. 006., str. 235.

9. Direktiva 2010/75/EU Europskog parlamenta i Vijeća od 24. studenoga 2010. o industrijskim emisijama (integrirano sprečavanje i kontrola onečišćenja), SL L 334, 17.12.2010., str. 17-119., Posebno izdanje na hrvatskom jeziku: Poglavlje 15., sv. 15., str. 159.

10. Direktiva 2011/92/EU Europskog parlamenta i Vijeća od 13. prosinca 2011. o procjeni učinaka određenih javnih i privatnih projekata na okoliš, SL L 26, 28.1.2012., str. 1., Posebno izdanje na hrvatskom jeziku: Poglavlje 15., sv. 027., str. 3.

11. Direktiva 75/440/EEZ od 16. lipnja 1975. o kvaliteti površinske vode namijenjene zahvaćanju pitke vode u državama članicama, SL L 194, 25.7.1975., str. 26.

12. Direktiva Vijeća 79/869/EEZ od 9. listopada 1979. o mjernim metodama i učestalosti uzorkovanja i analize površinske vode namijenjenih zahvaćanju pitke vode u državama članicama, SL L 271, 29.10.1979., str, 44.

13. Direktiva Vijeća 2013/51/Euratom od 22. listopada 2013. o utvrđivanju zahtjeva za zaštitu zdravlja stanovništva od radioaktivnih tvari u vodi namijenjenoj za ljudsku potrošnju, SL L 296, 7.11.2013., str. 12.

14. Direktiva Vijeća 76/160/EEZ od 8. prosinca 1975. o kakvoći vode za kupanje, SL L 31, 5.2.1976., str. 1.

15. Direktiva Vijeća 76/464/EEZ od 4. svibnja 1976. o onečišćenju uzrokovanom ispuštanjem određenih opasnih tvari u vodeni okoliš Zajednice, SL L 129, 18.5.1976., str. 23.

16. Direktiva Vijeća 78/659/EEZ od 18. srpnja 1978. o kvaliteti slatkih voda kojima je potrebna zaštita ili poboljšanje kako bi bile pogodne za život riba, SL L 222, 14.8.1978., str. 1.

17. Direktiva Vijeća 79/923/EEZ od 30. listopada 1979. o propisanoj kvaliteti vode u kojoj žive školjkaši, SL L 281, 10.11.1979., str. 47.

18. Direktiva Vijeća 80/68/EEZ od 17. prosinca 1979. o zaštiti podzemnih voda od onečišćenja izazvanog određenim opasnim tvarima, SL L 20, 26.1.1980., str. 43.

19. Direktiva Vijeća 80/778/EEZ od 15. srpnja 1980. o kvaliteti vode namijenjene ljudskoj potrošnji, SL L 229, 30.8.1980., str. 11.

20. Direktiva Vijeća 91/271/EEZ od 21. svibnja 1991. o pročišćavanju komunalnih otpadnih voda, SL L 135, 30.5.1991., str. 40., Posebno izdanje na hrvatskom jeziku: Poglavlje 15., sv. 001., str. 5.

21. Direktiva Vijeća 91/676/EEZ od 12. prosinca 1991. o zaštiti voda od onečišćenja uzrokovanog nitratima iz poljoprivrednih izvora, SL L 375, 31.12.1991., str. 1., Posebno izdanje na hrvatskom jeziku: Poglavlje 15., sv. 006., str. 6.

22. Direktiva Vijeća 92/43/EEZ od 21. svibnja 1992. o očuvanju prirodnih staništa i divlje faune i flore, SL L 206, 22.7.1992., str. 7., Posebno izdanje na hrvatskom jeziku: Poglavlje 15., sv. 002., str. 14.

23. Direktiva Vijeća 98/83/EZ od 3. studenoga 1998. o kvaliteti vode namijenjene za ljudsku potrošnju, SL L 330, 5.12.1998., str. 32, Posebno izdanje na hrvatskom jeziku: Poglavlje 15., sv. 006., str. 51.

24. Konvencija o pristupu informacijama, sudjelovanju javnosti u odlučivanju i pristupu pravosuđu u pitanjima okoliša, NN - MU, br. 1/2007.

25. Uredba (EZ) br. 648/2004 Europskog parlamenta i Vijeća od 31. ožujka 2004. o deterdžentima, SL L 104, 8.4.2004., str. 1., Posebno izdanje na hrvatskom jeziku: Poglavlje 13., sv. 053., str. 74.

26. Uredba Komisije (EU) br. 115/2010 od 9. veljače 2010. o utvrđivanju uvjeta za korištenje aktivnog aluminijevog oksida za uklanjanje fluorida iz prirodnih mineralnih voda i izvorskih voda, SL L 37, 10.2.2010., str. 13., Posebno izdanje na hrvatskom 
jeziku: Poglavlje 13., sv. 038., str. 241.

27. Ustav Republike Hrvatske, Narodne novine, br. 56/1990, 135/1997, 8/1998 - pročišćeni tekst, 113/2000, 124/2000 - pročišćeni tekst, 28/2001, 41/2001 - pročišćeni tekst, $55 / 2001$ - ispravak, 76/2010, 85/2010 - pročišćeni tekst, 5/2014.

28. Zakon o upravnim sporovima, Narodne novine br. 20/2010, 143/2012, 152/2014, 94/2016 - Odluka Ustavnog suda i 29/2017.

29. Zakon o vodama, Narodne novine, br. 153/2009, 63/2011, 130/2011, 56/2013, 14/2014.

30. Zakon o zaštiti okoliša, Narodne novine, br. 110/2007.

31. Zakon o zaštiti okoliša, Narodne novine, br. 80/2013, 153/2013 - Zakon o gradnji, $78 / 2015$.

Presude Suda EU-a i mišljenja nezavisnih odvjetnika

1. C-43/10 - Nomarchiaki Aftodioikisi Aitoloakarnanias and Others, Judgment of the Court (Grand Chamber) of 11 September 2012, ECLI:EU:C:2012:560 (presuda nije prevedena na hrvatski jezik).

2. C-461/13 - Bund für Umwelt und Naturschutz Deutschland, presuda Suda (veliko vijeće) od 1. srpnja 2015., ECLI:EU:C:2015:433.

3. C-529/15 - Folk, Presuda Suda (prvo vijeće) od 1. lipnja 2017., ECLI:EU:C:2017:419

4. C-664/15 - Protect Natur-, Arten- und Landschaftschutz Umweltorganisation, Judgment of the Court (Second Chamber) of 20 December 2017, ECLI:EU:C:2017:987 (presuda u trenutku pisanja rada nije bila prevedena na hrvatski jezik).

5. C-686/15 - Vodoopskrba i odvodnja, Presuda Suda (šesto vijeće) od 7. prosinca 2016. ECLI:EU:C:2016:927.

6. Mišljenje nezavisne odvjetnice Eleanor Sharpston od 12. listopada 2017., predmet C-664/15, ECLI:EU:C:2017:760.

7. Mišljenje nezavisnog odvjetnika Niila Jääskinena od 23. listopada 2014., predmet C-461/13, ECLI:EU:C:2014:2324.

Mrežni izvori

1. EUR-Lex, Sažeci zakonodavstva EU-a, Okoliš i klimatske promjene, Zaštita voda i gospodarenje vodama, http://eur-lex.europa.eu/summary/chapter/environment/2006. html?root=2006, pristup: 1 . veljače 2018 . 


\section{Lana Ofak*}

Summary

\section{HARMONIZATION OF CROATIAN LEGISLATION WITH EU LAW IN THE FIELD OF WATER PROTECTION WITH SPECIAL EMPHASIS ON PUBLIC PARTICIPATION AND ACCESS TO JUSTICE}

The legal protection of water is a field of law with the highest number of initiated infringement proceedings against EU member states related to violations of environmental law. In addition, the European State of Environment Report - State and Outlook in 2015 determined that EU member states were far from having healthy aquatic ecosystems, and the target of achieving a good status by 2015 was reached by only half of surface water bodies. This paper will analyse certain aspects of legal protection of water which EU Member States are obliged to provide under the Water Framework Directive. This paper will examine the compatibility of Croatian legislation with the provisions of the Water Framework Directive and the Convention on Access to Information, Public Participation and Access to Justice in Environmental Matters (Aarhus Convention), as interpreted by the Court of Justice in Judgments C-461/13 Bund für Umwelt und Naturschutz Deutschland ("Weser") and C-664/15 Protect Natur-, Arten- und Landschaftschutz Umweltorganisation. The paper will also offer some solutions for harmonizing Croatian legislation with the provisions of the Water Framework Directive and the Aarhus Convention.

Keywords: Water Framework Directive, Aarhus Convention, Water Act, Environmental Protection Act, Case Law of the Court of Justice of the European Union.

* Lana Ofak, Ph. D., Associate Professor, Faculty of Law, University of Zagreb; lana.ofak@ pravo.hr. 
Zussamenfassung

\section{DIE ANGLEICHUNG DER KROATISCHEN GESETZGEBUNG AN DAS EU RECHT IM BEREICH DES GEWÄSSERSCHUTZES UNTER BESONDERER BERÜCKSICHTIGUNG DER ÖFFENTLICHKEITSBETEILIGUNG AN ENTSCHEIDUNGSVERFAHREN UND DES ZUGANGS ZU GERICHTEN}

Im Bereich des rechtlichen Gewässerschutzes wurden die meisten Verfahren gegen die EU-Mitgliedstaaten wegen der Verletzung des Umweltrechtes eingeleitet. Darüber hinaus wurde im Europäischen Umweltbericht - Zustand und Ausblick 2015 - festgestellt, dass die EU-Mitgliedstaaten weit von der Durchsetzung gesunder Gewässerökologie sind und dass das Ziel des guten Zustands nur für die Hälfte der Binnengewässser erreicht wurde. Deshalb analysiert man in dieser Arbeit einzelne Aspekte des rechtlichen Gewässerschutzes, welche die EU-Mitgliedstaaten laut der Wasser-Rahmenrichtlinie versorgen müssen. Ebenfalls überprüft die Arbeit die Angeglichenheit der kroatischen Gesetzgebung an die Wasser-Rahmenrichtlinie und an das Übereinkommen über den Zugang zu Informationen, die Öffentlichkeitsbeteiligung an Entscheidungsverfahren und den Zugang zu Gerichten in Umweltangelegenheiten (Aarhus Konvention), welche der Gerichtshof der Europäischen Union in Urteilen C-461/13 Bund für Umwelt und Naturschutz Deutschland ("Weser") und C-664/15 Protect Natur-, Arten- und Landschaftschutz Umweltorganisation ausgelegt hat. Die Arbeit schlägt auch bestimmte Lösungen für die Angleichung der kroatischen Gesetzgebung an die Bestimmungen der Wasser-Rahmenrichtlinie und der Aarhus Konvention vor.

Schlüsselwörter: Wasser-Rahmenrichtlinie, Aarhus Konvention, Gewässergesetz, Umweltschutzgesetz, Rechtsprechung des Gerichthofs der Europäischen Union. 
Riassunto

\section{ADEGUAMENTO DELLA LEGISLAZIONE CROATA AL DIRITTO DELL'UE NELL'AMBITO DELLA TUTELA DELLE ACQUE CON PARTICOLARE ATTENZIONE ALLA PARTECIPAZIONE DEL PUBBLICO ED ALL'ACCESSO ALLA GIUSTIZIA}

La tutela giuridica delle acque è il campo del diritto che annovera il maggior numero di procedimenti avviati contro gli stati membri dell'Unione europea a causa di violazioni del diritto all'ambiente. Oltre a ciò, nella relazione europea sull'ambiente lo stato e le prospettive 2015. è stato accertato che gli stati membri dell'UE sono lontane dalla creazione di sistemi idrici ecosostenibili; posto che il fine della realizzazione di un buon sistema nel 2015 è stato raggiunto soltanto nella metà delle acque. In questo lavoro si analizzeranno gli aspetti della tutela legale delle acque che gli stati membri dell'UE sono obbligati ad assicurare in forza della Direttiva quadro sulle acque. Nel lavoro si disaminerà l'adeguamento della legislazione croata rispetto alla Direttiva quadro sulle acque e la Convenzione sull'accesso alle informazioni, la partecipazione del pubblico ai processi decisionali e l'accesso alla giustizia in materia ambientale (Convenzione di Aarhus), che la Corte di Giustizia dell'Unione europea ha richiamato nelle sentenze C-461/13 Bund für Umwelt und Naturschutz Deutschland ("Weser") e C-664/15 Protect Natur-, Arten- und Landschaftschutz Umweltorganisation. Nel lavoro verranno altresì offerte alcune soluzioni per l'adeguamento della legislazione croata con le disposizioni della Direttiva quadro sulle acque e la Convenzione di Aarhus.

Parole chiave: Direttiva quadro sulle acque, Convenzione di Aarhus, legge sulle acque, legge sulla tutela dell'ambiente, giurisprudenza della Corte di Giustizia dell'Unione europea. 
